\title{
Mutualism and asexual reproduction influence recognition genes in a fungal symbiont
}

M.A. van der $\mathrm{Nest}^{1}$, E.T. Steenkamp ${ }^{2}$, P.M. Wilken1, J. Stenlid 3 , M.J. Wingfield1, B.D. Wingfield 1 and B. Slippers $1 *$

${ }_{1}^{1}$ Department of Genetics, Forestry and Agricultural Biotechnology Institute (FABI), University of Pretoria, Pretoria, 0002, South Africa; ${ }^{2}$ Department of Microbiology and Plant Pathology, Forestry and Agricultural Biotechnology Institute (FABI), University of Pretoria, Pretoria, 0002, South Africa; ${ }^{3}$ Department of Forest Mycology and Plant Pathology, Swedish University of Agricultural Sciences, Uppsala, Sweden.

Corresponding author:

*E-mail: bernard.slippers@,fabi.up.ac.za

Tel: +27-12-420-3906

Fax: +27-12-420-3960

Present address:

Department of Genetics

Forestry and Agricultural Biotechnology Institute (FABI)

74 Lunnon Road, Hillcrest

Pretoria

0002

South Africa

\section{Research highlights:}

- We examined the mating system of the Amylostereum symbionts of Siricid woodwasps.

- Generally, polymorphism in their rabl pheromone receptor genes was limited.

- Surprisingly, rabl evolution was not linked to positive or balancing selection.

- Suppressed recombination and purifying selection appear to drive evolution of $r a b l$.

\section{Key words:}

Symbiosis, Amylostereum areolatum, Sirex noctilio, pheromone receptor and evolution.

\section{ABSTRACT}

Mutualistic symbiotic interactions between microbes and insects are wide-spread in nature. Alignment of the reproductive interests of the organisms involved in a symbiotic interaction, typically involves clonal reproduction of the microbial symbiont that is transmitted vertically by the insect partner. In this study, we used the Amylostereum fungus-Sirex woodwasp mutualism to 
consider whether the prolonged association and predominantly asexual mode of reproduction have affected the mating system of the fungal partner. DNA sequence information for the pheromone receptor gene $r a b l$ encoded at the mat-B locus, as well as the eukaryotic translation elongation factor $1 \alpha$ gene and the ribosomal RNA internal transcribed spacer region were utilized. The identification of rabl alleles in A. chailletii and A. areolatum populations revealed that this gene is more polymorphic compared to the other two regions, although the diversity of all three regions was lower than the corresponding genes in other free-living Agaricomycetes. Our results indicated that suppressed recombination might potentially be implicated in the diversification of rabl, while no evidence of balancing selection was detected. In addition, positive selection was detected at only two codons suggesting that purifying selection rather than positive selection represents an important driving force in the evolution of rabl. Therefore, the long-term symbiotic relationship with their insect partners has not only affected the diversity at this mating-type locus, but it has also influenced the manner in which selection drives and maintains this diversity in $A$. areolatum and $A$. chailletii. 


\section{INTRODUCTION}

Most eukaryotic organisms reproduce sexually to generate offspring even though it is more costly than asexual reproduction (e.g., Barton and Charlesworth 1998; Otto 2003). This costly reproductive strategy could be maintained because recombination acts to provide advantageous genotypes necessary for adaptation to changing environments or because recombination acts to eliminate deleterious mutations (e.g., Zeyl and Bell 1997; Taylor et al. 1999; Neiman et al. 2010). Both of these hypotheses are consistent with the fact that the absence of sexual reproduction decreases the overall fitness of an organism and could ultimately lead to extinction (Butlin 2006; Paland and Lynch 2006; Howe and Denver 2008). An observation in fungi is that most asexually reproducing populations retain some level of sexual reproduction, despite its cost, thus generally favouring a system of mixed modes of reproduction (Taylor et al. 1999; Hsueh and Heitman 2008).

Notwithstanding the advantages, mixed modes of sexual and asexual reproduction appear not to be feasible in all organisms. For example, the fungal symbionts of insects mainly reproduce asexually and are transmitted from mother to offspring in a vertical fashion (Chapela et al. 1994; Judson and Normark 1996). These modes of reproduction and transmission ensure codependence between the symbiotic partners, but could lead to a reduction in genetic diversity (Rispe and Moran 2000; Mira and Moran 2002). The absence of sexual recombination could also result in an accumulation of mildly deleterious mutations, increased genetic drift, more rapid sequence evolution (i.e., excess of amino acid substitutions), a shift in nucleotide base composition due to mutational bias and genome erosion (Rispe and Moran 2000; Kaltenpoth et al. 2010). Nevertheless, several ancient lineages of asexually reproducing organisms still exist in successful symbiotic relationships (Welch and Meselson 2001; Jany and Pawlowska 2010). In 
these relationships, it is thought that selection by the host might limit the accumulation of deleterious mutations in the symbiont (Kaltenpoth et al. 2010).

In this study, we considered the ancient and obligate symbiotic relationship between the wood-rotting fungus Amylostereum areolatum and its hymenopteran Siricid insect partner, Sirex noctilio. In this relationship, the fungus is necessary for the development of the larvae, while the woodwasp spreads the asexual spores and/or mycelium of the fungus (Vasiliauskas et al. 1998, Thomsen and Koch 1999), thereby facilitating vertical transmission of A. areolatum (Madden 1981). Like other fungal symbionts of insects (Chapela et al. 1994; Judson and Normark 1996), A. areolatum can also reproduce sexually and has a tetrapolar mating system, i.e., the genes governing sexual recognition in the fungus are present on two unlinked mating type loci (mat- $A$ and $m a t-B$ ) (Boidin and Lanquetin 1984; van der Nest et al. 2008; 2009). In fungi with tetrapolar mating systems, the mat- $A$ locus harbours genes that encode homeodomain proteins (functional transcriptional factors), while the mat-B locus harbours genes that encode peptide pheromones and pheromone receptors (e.g., Brown and Casselton 2001; Heitman et al. 2007). The sexual sporocarps of these fungi are, however, rarely found in nature and usually only in the native range of the insect and fungus (Vasiliauskas and Stenlid 1999; Slippers et al. 2003; Nielsen et al. 2009). The population biology of these fungi also suggests that, like other insect symbionts, they rely on the woodwasp for the effective spread of asexual spores (Vasiliauskas et al. 1998; Vasiliauskas and Stenlid 1999; Thomsen and Koch 1999).

The evolutionary forces acting on the mat loci are thought to drive divergence between mat alleles, thus ensuring compatibility between individuals in a population (e.g., May et al. 1999; Devier et al. 2009). A form of balancing selection, known as negative frequency-dependent selection, probably acts to preserve the characteristically high allelic and nucleotide diversities at 
these loci (May et al. 1999). This mechanism involves the selection for rare alleles, because individuals carrying such rare alleles will be sexually compatible with a larger proportion of other individuals in the population (May et al. 1999; Ruggiero et al. 2008). Diversity at the mat loci of eukaryotes is also promoted by accelerated evolutionary rates, which is evident in the increased frequency of non-synonymous substitutions located in these regions (Vicoso et al. 2008; Devier et al. 2009). These high rates of substitution could be ascribed to suppressed recombination and/or positive selection, where the former prevents the loss of mutations and the latter acts to maintain beneficial amino acid substitutions (Uyenoyama 2005; Menkis et al. 2008; Vicoso et al. 2008).

The overall aim of this study was to determine whether the symbiotic relationship between $A$. areolatum and $S$. noctilio, together with a predominantly asexual mode of reproduction in the fungus, has influenced the evolution of the genes determining sexual recognition in the fungal partner. Two specific questions were addressed: i) How does the pattern and extent of polymorphism at a mat locus compare to those in other regions of the genome? (ii) Which evolutionary forces most likely influence the patterns and rates of polymorphism at the mat loci? To answer these questions we utilized DNA sequence information for the pheromone receptor gene $(r a b 1)$ encoded at the mat- $B$ locus, as well as the eukaryotic translation elongation factor $1 \alpha$ (Tef-1 $\alpha$ ) gene and the ribosomal RNA (rRNA) internal transcribed spacer (ITS) region, which includes the spacers ITS1, ITS2 and the 5.8S rRNA gene. The rab1 gene has been demonstrated previously to be involved in sexual recognition in A. areolatum (van der Nest et al. 2008). For comparison, we included data from the closely related species $A$. chailletii that more frequently reproduces sexually (Vasiliauskas et al. 1998; Vasiliauskas and Stenlid 1999; Slippers et al. 
2001). Finally, these systems were also compared with those of other free-living Agaricomycetes.

\section{MATERIALS AND METHODS}

\section{$2.1 \quad$ Fungal strains}

Heterokaryotic isolates of $A$. areolatum (CMW16848) and A. chailletii (NAc3) were included for the identification and characterization of pheromone receptor genes. Additionally, twenty-five isolates each of $A$. areolatum and $A$. chailletii obtained from various culture collections were included to investigate the allelic variation and diversity of pheromone receptor genes in naturally occurring isolates (Supplementary Tables 1 and 2). These isolates were selected to capture the known diversity of the fungi and were collected from South Africa, Brazil, Argentina, Australia, New Zealand, United States of America, Canada, France, Sweden, United Kingdom, Switzerland, Denmark, Norway, Austria, Italy, Greece and Lithuania. Working cultures of these heterokaryons were maintained on potato dextrose agar (PDA) $\left(24 \mathrm{gL}^{-1}\right.$ of PDA,

$1 \mathrm{gL}^{-1}$ glucose, and $1 \mathrm{gL}^{-1}$ yeast extract) (Biolab, Johannesburg, South Africa). All of the isolates used in this study are also maintained at $4{ }^{\circ} \mathrm{C}$ in the culture collection (CMW) of the Forestry and Agricultural Biotechnology Institute (FABI), University of Pretoria, Pretoria, South Africa. Genomic DNA was collected from the isolates using the method described by Zhou et al. (2004).

\subsection{PCR, cloning and nucleotide sequencing of the rab1 gene}

A large portion of the the rabl gene sequence for A. areolatum (CMW16848) was available from a previous study (van der Nest et al. 2008), while that for A. chailletii was identified using degenerate PCR primers (br1-F and br1-R; Supplementary Table 3) designed by James et al. 
(2004b). All PCRs were performed on an Eppendorf thermocycler (Eppendorf AG, Germany) using reaction mixtures containing $1 \mathrm{ng} / \mu 1 \mathrm{DNA}, 0.2 \mathrm{mM}$ of each of the four $\mathrm{dNTPs}, 1.5 \mathrm{mM}$ $\mathrm{MgCl}_{2}, 0.5 \mu \mathrm{M}$ of each primer and 2.5 U FastStart Taq (Roche Diagnostics, Mannheim). Thermal cycling conditions consisted of an initial denaturation step at $94{ }^{\circ} \mathrm{C}$ for 2 min followed by 30 cycles of denaturation at $94{ }^{\circ} \mathrm{C}$ for $30 \mathrm{~s}$, annealing at $50{ }^{\circ} \mathrm{C}$ for $30 \mathrm{~s}$, extension at $72{ }^{\circ} \mathrm{C}$ for $30 \mathrm{~s}$, and a final extension at $72{ }^{\circ} \mathrm{C}$ for $10 \mathrm{~min}$. The resulting PCR products were purified using polyethylene glycol (PEG) precipitation (Steenkamp et al., 2006) and the purified PCR products were cloned using the pGEM-T Easy vector System I (Promega Corporation, Madison, USA). PCR products were cloned in order to obtain haplotype phases of all sequences derived from the heterokaryotic isolates. The cloned products were amplified from individual colonies with plasmid-specific primers (Steenkamp et al., 2006), after which the PCR products were purified using PEG precipitation. The purified products were then sequenced with the plasmid-specific primers, Big Dye Cycle Sequencing kit version 3.1 (Perkin-Elmer, Warrington, UK) and an ABI3700 DNA analyzer (Applied Biosystems, Foster City, USA).

To obtain the sequences upstream and downstream of these fragments in A. areolatum and $A$. $\begin{array}{lllllll}\text { chailletii, nested PCR primers designed with Primer } 3 & \text { (cgi v0.2) }\end{array}$ (http://www.genome.wi.mit.edu/genome_software/other/primer3.html) and PCR-based genome walking (Siebert et al. 1995) were used. The nested primers used for genome-walking included RAB1-4 (Supplementary Table 3) for A. areolatum and RAB5 (Supplementary Table 3) for $A$. chailletii. The remaining portion of the pheromone receptor gene for A. chailletii was obtained using a primer (RAB6; Supplementary Table 3) based on the sequence of $A$. areolatum. These PCR products were amplified, cloned and sequenced as described above. 
All sequence files were analyzed with Chromas Lite 2.0 (Technelysium) and BioEdit version 7.0.2.5 (Hall 1999). They were also compared to those in the protein database of the National Centre for Biotechnology Information (www.ncbi.nih.nlm.gov) using BlastX. To predict the features in the secondary structure of the Rabl protein, we used TOPCON (http://topcons.cbr.su.se/), which calculates consensus predictions using a Hidden Markov Model and inputs five commonly used topology prediction methods (Bernsel et al., 2009).

\subsection{Allelic variation and diversity of rab1, Tef-1 $\alpha$ and ITS}

To identify unique rabl alleles in $A$. areolatum and $A$. chailletii, we used two approaches to discover polymorphisms among a diverse set of 25 isolates of each species. The one approach entailed analysis a 186-base pair (bp) region of rabl, which was previously shown to be polymorphic (van der Nest et al. 2008). This fragment was amplified and sequenced using primer set RABF+RABR (Supplementary Table 3). The second approach involved PCR-RFLP (restriction fragment length polymorphism) analysis of a 682-bp fragment of the rabl gene. For this purpose, PCR products were generated with primers RAB1-470F and RAB1-1800R (Supplementary Table 3 ) for the 25 isolates of $A$. areolatum. The amplicons were then digested with the enzyme EcoRV (Roche Diagnostics) and visualised with agarose gel (Roche Diagnostics) electrophoresis (Sambrook et al. 1989; van der Nest et al. 2008).

Based on the polymorphisms observed, a set of 13 isolates for each of A. areolatum and $A$. chailletii, were selected. For these isolates, the 682-bp portion of the rab1 gene was sequenced for $A$. areolatum, as well as for $A$. chailletii using primer set RAB7+RAB8 (Supplementary Table 3). For comparative purposes, portions of the two housekeeping loci, ITS and Tef-1 $\alpha$, were also amplified and sequenced for the 13 isolates of each species. Primer set ITS1+ITS4 (Supplementary Table 3; White et al. 1990) was used to amplify of the ITS region of both 
species. For the Tef-1 $\alpha$ region, the primer set TEFac1+TEFac2 (Supplementary Table 3) was used for A. chailletii and primer set TEFaa1+TEFaa2 (Supplementary Table 3) for A. areolatum. Other than those used for the PCR-RFLPs, all the Tef-1 $\alpha$ and ITS PCR products, as well as both of the 186- and 682-bp fragments of rabl, were purified, cloned and at least 5 clones per individual were sequenced, as described above.

Following sequence analysis with Chromas Lite and BioEdit, sequence alignments for each locus were produced using MAFFT version 5.85 (http://mafft.cbrc.jp/alignment/server/) (Katoh et al. 2002). For each of the datasets, nucleotide diversity ( $\pi$; Nei and Li 1979) was determined using the software package DnaSP version 5.10 (Librado and Rozas 2009), while allelic frequencies were calculated using GENEPOP software version 1.2. Because a limited number of clones were sequenced per individual, the possibility of underestimating allelic diversity could not be excluded.

\subsection{Molecular evolution of rab1}

To identify the evolutionary forces acting on the pheromone receptor genes of A. areolatum and A. chailletii, all the unique rabl alleles identified in this study were examined. The A. areolatum rabl alleles were amplified and sequenced using primer set RAB9+RAB10 (Supplementary Table 3) for isolates CMW8900 and CMW2822, while the identified A. chailletii rabl alleles were amplified and sequenced using primer set RAB11+RAB12 (Supplementary Table 3) for isolates LIIAc116, DAC2, US2 and It1.8.

The CODEML program in the PAML version 3.14 package (Yang and Nielson 2002) was used to determine patterns of selective pressure acting on the pheromone receptor alleles identified in the two fungi. The phylogenetic tree required by CODEML was generated by 
subjecting a MAFFT-generated nucleotide alignment of rabl to a maximum likelihood (ML) analyses using PhyML version 3.0 software (Guindon and Gascuel 2003). This ML analysis employed gamma correction $(\mathrm{G})$ to account for among site rate variation, a proportion of invariable sites (I) and the HKY (Hasegawa et al. 1987) nucleotide substitution model as indicated by jModeltest version 0.1.1 and the Akaike Information Criterion (Posada 2008).

Positive selection was evaluated by computing $\omega$ across all the sites for each of the loci (Yang et al. 2000; Devier et al. 2009), where $\omega$ reflects the non-synonymous $(d N) /$ synonymous (dS) substitution rate ratio (Yang and Nielson, 1998). To test for variation of selective pressures across the codons, goodness of fit was calculated for the different site-specific models proposed by Yang et al. (2000). Statistical significance was calculated with likelihood ratio tests (LRT), which entailed analysis of the $\chi^{2}$ distribution of $2 \Delta \ln$ (i.e., twice the log likelihood difference between the two models) values for the different models (Yang and Nielson 1998), where the degrees of freedom were equal to the differences in number of parameters between the two models (Yang et al. 2000).

To determine whether balancing selection acts on rabl to maintain rare alleles over long evolutionary times (Vieira et al. 2008), a phylogenetic tree based on the amino acid sequences of the pheromone receptors present in A. areolatum, A. chailletii and sequences from other Basidiomycetes and Ascomycetes available in GenBank was constructed (See Figure 3 for accession numbers for the pheromone receptors of other fungi). The amino acid sequences were aligned using MAFFT and an ML phylogeny inferred with PhyML, which utilized the LG (Le and Gascuel, 2008) model of amino acid substitution, I and the observed amino acid frequencies, as indicated by ProtTest 2.4 (Abascal et al. 2005). Branch support was determined using PhyML with the same best-fit model and 1000 bootstrap replicates. Both the tree and dataset have been 
submitted to TreeBASE (http://www.treebase.org/treebase/index.html) and the Study Accession URL is: http://purl.org/phylo/treebase/phylows/study/TB2:S12966.

DnaSP was used to study the extent of recombination within the rabl, ITS and Tef-1 $\alpha$ regions examined. The recombination parameter R was calculated (Hudson 1987), while the minimum number of recombination $\left(\mathrm{R}_{\mathrm{M}}\right)$ events during the history of the species (Hudson and Kaplan 1985) was estimated using neutral coalescence simulations, based on the number of segregating sites, intermediate levels of recombination and 10000 replications (Librado and Rozas 2009). The extent of recombination within each species was also compared by examining single-locus phylogenies for incompatibility. The latter analyses were based on separate trees inferred from the DNA sequence information for the three loci of the 13 selected isolates of each of $A$. areolatum and A. chailletii. MAFFT-generated datasets were subjected to PhyML analyses using best-fit model parameters, as described before. ML analysis of the rabl dataset employed the HKY with I and G, the ITS dataset employed the TrNeF model (Tamura and Nei 1993; Posada 2008), and the Tef-1 $\alpha$ dataset employed the TrN model (Tamura and Nei 1993; Posada 2008). For each dataset, branch support was determined using the respective best-fit models and 1000 bootstrap replicates. To assess congruencies between the resulting gene trees, a strict consensus tree was computed using Mega software version 4.0.2 (Kumar et al. 2008). The partition homogeneity test using PAUP version 4.0b10 (Swofford 2000) was used to examine the null hypothesis of recombination in A. areolatum and A. chailletii (Houbraken et al. 2008). Significance was assigned by comparing the summed tree length from the actual data to those from 100 artificial datasets. 


\section{RESULTS}

\subsection{PCR, cloning and nucleotide sequencing of the rab1 gene}

It was possible to identify and sequence the complete pheromone receptor gene rabl (1539 bp) in A. areolatum, as well as a large portion of the gene in A. chailletii (1265 bp). Typical of pheromone receptors, the inferred amino acid sequences for the Amylostereum Rab1 (Fig. 1) harboured the seven transmembrane-spanning helices that are characteristic of the rhodopsinlike superfamily of G protein-linked receptors, as well as extracellular and cytoplasmic loop domains and a long cytoplasmic tail (e.g., James et al. 2004a; Raudaskoski and Kothe 2010). The rabl gene also contained five introns (Fig. 1), which are comparable with those reported for the pheromone receptors of Coprinopsis cinerea that has four or five, Coprinellus disseminatus that has five and Schizophyllum commune that has three introns (Vaillancourt et al. 1997; James et al. 2006). The position of introns $2-5$ closely corresponded to those in previously identified receptor sequence introns, while intron 1 in the rab1 N-terminal appears to represent a novel position (Fig. 1). The position and size of the introns present in the rabl genes in A. chailletii and $A$. areolatum were similar, except that the last intron in $A$. chailletii was larger than in $A$. areolatum.

\subsection{Allelic variation and diversity of rab1, Tef-1 $\alpha$ and ITS}

A total of 8 and 6 polymorphisms were observed within the 186-bp alignment of rabl for the 25 representative isolates of each of $A$. areolatum and A. chailletii, respectively (Supplementary Tables 1 and 2). For 13 of the 25 representative isolates of $A$. areolatum and of $A$. chailletii, a larger portion of the rabl gene, as well as a portion of Tef- $1 \alpha$ and ITS were also analysed. Following cloning of each PCR product, sequencing and alignment, the datasets for ITS, Tef- $1 \alpha$ 
and $r a b 1$ in these representative isolates consisted of 606, 474 and 682 nucleotides, respectively. Based on the sequence alignments, two types of Tef- $1 \alpha$ were identified. The GenBank accession numbers for the two types of Tef- $1 \alpha$ identified in A. areolatum are HQ864714 and HQ864713, respectively. Because the one type contained a premature stop codon, it was considered a pseudogene and was not included in subsequent analyses.

Among the Tef-1 $\alpha$, ITS and rabl sequences of the 13 representatives of $A$. areolatum and of A. chailletii, a total of 19 (Supplementary Table 4) and 24 (Supplementary Table 5) nucleotide polymorphisms, respectively, were identified. However, in both species, about half of the polymorphisms were located in the rabl dataset. As a result, the nucleotide diversity or $\pi$-values (0.004 and 0.02, respectively) for the rabl regions in A. areolatum and A. chailletii were generally higher than the $\pi$-values for the ITS and Tef- $1 \alpha$ regions (Table 1).

Among the 13 representatives for each species, the number of alleles identified in the three genes ( $r a b 1$, ITS and Tef- $1 \alpha)$ investigated ranged from 2 to 6 for $A$. areolatum and 3 to 5 for $A$. chailletii (Figure 2A). With regards to rabl, the same three alleles that were identified within the set of $13 \mathrm{~A}$. areolatum isolates were also detected in the set of $25 \mathrm{~A}$. areolatum isolates collected in different regions of the world (Supplementary Table 4). In contrast, an additional rabl allele was detected in the global collection of 25 A. chailletii isolates. The A. chailletii isolates included in this study thus harboured at least four pheromone receptor alleles (Supplementary Tables 2 and 5), although some apparently occur at very low frequencies (Fig. 2A). These findings were also supported by the PCR-RFLP analysis with EcoRV.

The GenBank accession numbers for the $A$. areolatum and $A$. chailletii ITS sequences are KC865539-KC865592, the A. areolatum and A. chailletii rabl sequences are KC865479- 
KC865530, while the accession numbers for A. areolatum and A. chailletii Tef- $1 \alpha$ are KC865425-KC865478.

Heterozygous and homozygous genotypes were detected in both A. chailletii and A. areolatum for all three gene regions investigated (Fig. 2B). Nine, 8 and 5 unique ITS, Tef- $1 \alpha$ and rabl genotypes were identified for the A. chailletii individuals. Among the A. areolatum isolates respectively 3, 7 and 3 ITS, Tef- $1 \alpha$ and $r a b 1$ genotypes were identified. Compared to $A$. areolatum, the $A$. chailletii individuals thus harboured considerably more unique ITS ( 9 vs. 3 ) and rabl (5 vs. 3) genotypes. Amylostereum chailletii also included many more genotypes represented by a single individual (i.e., 6 vs. 1 ITS genotypes and 2 vs. 0 rabl genotypes) in comparison with $A$. areolatum. Some of the identified genotypes were over-represented. For example, $76.9 \%$ of the A. areolatum individuals shared the same ITS genotype (Fig. 2B). These over-represented genotypes were also homozygotic, with both nuclei of the heterokaryon having the same allelic state.

\subsection{Molecular evolution of rab1}

A large proportion of the three $A$. areolatum rabl (1579 bp) alleles, as well as the five $A$. chailletii rab1 (1448 bp) alleles were sequenced (GenBank accession numbers KC865531865538) (Fig. 1). In A. areolatum, alleles shared 99.0-99.9\% nucleotide sequence identity with 15 polymorphic sites (Supplementary Table 6). The alleles in A. chailletii shared more than 98.0 $\%$ nucleotide sequence identity with each other (Supplementary Table 6), while they shared only $83 \%$ nucleotide sequence identity with the $A$. areolatum rabl alleles. This suggests that all the alleles belong to the same sub-locus. This follows from the fact that the pheromone receptors in C. cinerea belonging to the same sub-locus are $>60 \%$ similar, while those in different sub-loci are $<32-35 \%$ similar (Riquelme et al. 2005). 
Comparison of the rabl.1 allele with the rabl.2 and the rabl.3 alleles in A. areolatum revealed two polymorphic sites that result in non-synonymous amino acid substitutions (present in the long cytoplasm carboxy-terminal intracellular tail) (Fig. 1). The single polymorphic site identified in the rab1.2 and rab1.3 alleles represented a silent substitution, which suggests that the rab1.2 and rabl.3 alleles are functionally equivalent in sharing the same mating type specificity. Several non-synonymous substitutions were identified among the rabl alleles present in A. chailletii (Fig. 1), including one in transmembrane region 1, one in the transmembrane region 5, two in the intracellular loop 3 and two in the long cytoplasm carboxy-terminal intracellular tail.

Calculations using model M3 with variable selective pressures acting on the codons and models that assume no selection (M0) provided a better fit for rabl (Table 2). The log likelihood difference between M3 and M0 was 4.57 with a significant $\chi^{2}$ distribution test result $(\mathrm{P}<0.05)$, while the log likelihood differences were not significant for M2 and M1, M5 and M1, M6 and M1 or for M8 and M7. Therefore, the positive-selection models (M2, M5, M6 and M8) did not provide a better fit in comparison to models that assume no positive selection (M1 and M7). Even though the models that assume positive-selection did not provided a better fit, all of these models identified two positively selected codons (codons 256 and 373) respectively located in the intracellular loop EL3 region and in the long cytoplasm carboxy-terminal intracellular tail. However, at the $95 \%$ level, only models M5 and M6 identified these codons as being subject to positive selection (Table 2).

The rab1 alignment (consisting of 337 amino acids) and ML phylogeny included sequences of the A. areolatum and A. chailletii rabl alleles identified in this study, as well as sequences from the pheromone receptors present in other Basidiomycetes and Ascomycetes (Fig. 3). All of 
the Amylostereum pheromone receptors grouped in the same major cluster. The putative pheromone receptors of $A$. areolatum and $A$. chailletii appeared to be each other's closest neighbours and they grouped together with proteins from $C$. cinerea (including CcSTE3.3, Rcb3B43, AAQ96346) and L. bicolor (including LbSTE3.3, 192000).

No evidence of recombination within rabl, ITS or Tef- $1 \alpha$ for $A$. areolatum and $A$. chailletii was detected. This is because of the low values for the recombination parameters ( $R$ and $\left.R_{M}\right)$ (Table 3) that were observed for all three loci in both species, suggesting that meiotic recombination between segregating sites is limited (Garg et al. 2007). However, evidence of recombination among individuals was detected in this study. Two distinct clades were identified for all three the genes, with one clade including only $A$. areolatum isolates and the other only $A$. chailletii isolates (Supplementary Figures 1A, 1B and 1C). Clonal lineages were observed between the three trees for both the species. For example, the alleles of the A. areolatum isolates from the Southern Hemisphere grouped together for all three the genes (Supplementary Figures 1A, 1B and 1C). However, consistent with the results of the partition homogeneity test $(P<$ 0.001), incongruences were also observed among the rabl, Tef- $1 \alpha$ and ITS phylogenies (Supplementary Figures 1A, 1B and 1C). For example, the alleles of the A. areolatum isolates obtained from Southern Hemisphere countries grouped together with different isolates for each of the gene trees. No structure was evident in the strict consensus tree for either A. areolatum and A. chailletii (Supplementary Figure 1D), suggesting that recombination is restricted to withinspecies interactions. 


\section{DISCUSSION}

This study represents the first attempt to investigate the evolution of a mating type locus of a fungus involved in an obligate mutualism with an insect. The Amylostereum-Sirex association has impacted significantly on the biology and evolution of the fungal partner, similar to that observed in other symbionts. This is reflected in the predominantly asexual mode of reproduction of $A$. areolatum and $A$. chailletii and their overall low genetic diversity. The data presented here clearly demonstrate higher levels of diversity in the rabl pheromone receptor in A. areolatum and $A$. chailletii compared to ITS and Tef- $1 \alpha$. However, the diversity of all three genes was lower than the corresponding genes in other free-living Agaricomycetes. Rather than positive or balancing selection, purifying selection represents an important driving force in the evolution of rabl in A. chailletii and A. areolatum. Our study thus suggests that the long-term symbiotic relationship with their insect partners has not only affected the diversity at this locus, but it has also impacted on the manner in which selection drives and maintains this diversity in $A$. areolatum and A. chailletii.

Comparison of the inferred amino acid sequences of the Amylostereum rabl with those in other Agaricomycetes revealed that they share the same structure and conserved domains (e.g., James et al. 2004a; Raudaskoski and Kothe 2010). The Rab1 protein is thus likely to function in the same way as pheromone receptors of other fungi. In yeast, a conformational change in the receptor causes the release of the $G$ protein bound to the pheromone receptor protein when the pheromone binds to the pheromone receptor protein. This results in the activation of the MAP kinase signalling that activates specific transcriptional factors involved in mating and heterokaryon formation (Marsh et al. 1991). To confirm that this occurs in Amylostereum, it will be necessary to do transcript profiling and functional analyses. 
Identification of naturally occurring pheromone receptor rabl alleles in $A$. chailletii and $A$. areolatum revealed that these genes are multi-allelic and polymorphic. This is consistent with what is known for other fungi with tetrapolar mating systems (e.g., May et al. 1999; Kothe et al. 2003; Riquelme et al. 2005, Devier et al. 2009). Both A. areolatum and A. chailletii displayed nucleotide diversities for $r a b l$ that are higher than the values observed for their corresponding ITS and Tef- $1 \alpha$ sequences. This is similar to what has previously been found for other eukaryotes (e.g., May et al. 1999; James et al. 2001; Devier et al. 2009) where the genes controlling sexual recognition are more polymorphic and diverse than the rest of the genome. The pheromone receptor encoded by rabl in the fungi examined is thus subject to selection for diversification.

Previous work on sex-related genes has shown that their diversification may be driven by balancing selection and suppressed recombination (Meyer and Thomsen 2001; Uyenoyama 2005). Balancing selection is known to maintain fungal mating type alleles distributed throughout populations at roughly equal frequencies (James et al. 2001). However, we found no evidence for balancing selection operating on the rabl alleles of Amylostereum. All of the rabl alleles in $A$. areolatum and $A$. chailletii clustered in a species-specific manner, closely with the pheromone receptor genes CcSTE3.3 in C. cinerea and LbSte3.3 in L. bicolor (Niculita-Hirzel et al. 2008; Martinez et al. 2009). Neither species thus harboured traces of trans-species polymorphism, which is a hallmark of balancing selection (Vieira et al. 2008; Devier et al. 2009). Nevertheless, no evidence of recombination within the region of the rabl analysed was detected, which is in agreement with the notion that allelic diversity of eukaryotic recognition loci is influenced by suppressed recombination (e.g., Uyenoyama 2005; Menkis et al. 2008). Our 
results thus suggest that suppressed recombination and not balancing selection could explain the higher levels of diversity in the rabl gene of $A$. chailletii and A. areolatum.

Positive selection is also known to maintain high levels of diversity of sex-related genes (e.g., Civetta and Singh 1998, Karlsson et al. 2008). As expected, we detected the effects of positive selection on the Amylostereum rabl, albeit only at two codons of the gene. One of the codons is situated in the third extracellular (loop EL3) of the inferred Rab1 receptor protein. In fact, a large proportion (27\%) of the non-synonymous substitutions occurring between the $A$. areolatum and $A$. chailletii rabl alleles were also located in this region. These results are consistent with previous reports that the first and third extracellular loops of the pheromone receptor are usually more variable, because these regions interact with the mating pheromones (Reneke et al. 1988, Niculita-Hirzel et al. 2008). The second codon potentially under positive selection is located in the long C-terminal cytoplasmic tail following the last transmembrane domain, a region that also harboured a large proportion of the non-synonymous substitutions between $A$. areolatum and $A$. chailletii.

It is likely that one or more of the non-synonymous substitutions identified in rabl may determine mating type specificity. This could be true for either of the codons under positive selection, or any other of the non-synonymous substitutions between $A$. areolatum and $A$. chailletii detected in this study. For example, the non-synonymous substitutions located in the third extracellular loop region EL3 of the pheromone receptor that interacts with the mating pheromones (Reneke et al. 1988, Niculita-Hirzel et al. 2008) could alter the mating type specificity. Non-synonymous substitutions located in the third intracellular region (loop IL3) and the C-termini cytoplasmic tail have also been implicated in mating type specificity as both these regions of the receptor interact with $G$ proteins and affect $G$ protein signalling (Hegner et al. 
1999; Gola et al. 2000; Marsh et al. 1991; Karlsson et al. 2008). In A. areolatum and A. chailletii, the possibility cannot be excluded that another pheromone receptor closely linked to rabl may determine mating type specificity, although rabl.1 and rabl.2 have previously been shown to co-segregate with mating type specificity in A. areolatum (van der Nest et al. 2009). Future genome sequence-based studies will determine whether these substitutions or those located at other receptors confer mating type specificity in Amylostereum.

The results presented here suggest that the entire $r a b 1$ gene is under purifying selection and not positive selection (Table 2), which is different to what might have been expected (e.g., Civetta and Singh 1998, Karlsson et al. 2008). The $\omega$-values for rabl in these fungi were significantly below 1 , indicating that purifying selection was responsible for eliminating most amino acid substitutions that might have arisen. Similar results have been obtained for Microbotryum spp. (Devier et al. 2009). These fungi also have a tetrapolar mating type system, but they predominantly represent self-fertilizers that require only two pheromone receptor alleles and apparently do not need positive selection to generate and maintain additional alleles. A similar situation may exist in $A$. areolatum, which also appears to have only two functional rabl alleles, based on differences at the amino acid level, that could alter mating type specificity. The possibility that there are additional alleles at this locus that were missed in this study cannot be excluded, even though we sampled from various regions of the world. Nevertheless, our results suggest that purifying selection represents an important driving force in the evolution of rabl in A. chailletii and A. areolatum.

The nucleotide diversities for rabl, ITS and Tef- $1 \alpha$ in A. areolatum and A. chailletii were all much lower than those observed for the regions examined in other fungi (e.g., Ciampi et al. 2009, Engh et al. 2010). For example, the rabl alleles of $A$. areolatum and A. chailletii shared 
high levels of sequence identity (between $97 \%$ and $99 \%$ nucleotide identity), while pheromone receptors from the same sub-group in S. commune share only $90 \%$ sequence identity (Wendland and Kothe 1996; Gola and Kothe 2003). Also, the A. areolatum and A. chailletii rab1 nucleotide diversity values were considerably lower than those reported for Coprinellus disseminatus (James et al. 2006) and S. lacrymans (Engh et al. 2010). Similarly, the observed $\pi$-values for the ITS and Tef- $1 \alpha$ regions in $A$. areolatum and $A$. chailletii were significantly lower than the values observed for these genes in S. lacrymans (Engh et al. 2010). The low nucleotide diversities observed for the Amylostereum rabl gene thus appear to be associated with limited genetic diversity at other unlinked loci. This is consistent with previous observations that the overall genetic diversity of $A$. areolatum and $A$. chailletii is generally very low (e.g., Vasiliauskas et al. 1998; Vasiliauskas and Stenlid 1999). Compared to free-living Agaricomycetes, A. areolatum and $A$. chailletii have a low overall genetic diversity as well as a low genetic variation at their mat- $B$ locus. This low diversity could be due to the close association between these fungi and their woodwasp vectors.

Collectively, the results of this study suggest that the patterns of polymorphism observed at rabl in A. areolatum and A. chailletii are determined by the combined effects of the selection and demographic processes brought about by the unique lifestyle of these fungi. For example, inbreeding and/or asexuality in A. areolatum and A. chailletii could explain the low nucleotide diversity of the genes revealed in this study (Glémin et al. 2006; Haag and Roze 2007; Haudry et al. 2008). Similar observations have also been made for other microbial symbionts with reduced levels of recombination and effective population sizes (Rispe and Moran 2000; Mira and Moran 2002). However, recombination does not appear to be completely absent in A. areolatum and $A$. chailletii because the results showed that both species are characterized by unique multi-locus 
genotypes among individuals (Supplementary Tables 4 and 5) and by incongruencies among the phylogenies inferred from the three loci studied (Supplementary Figure 1). Our results thus highlight the fact that, despite a predominant asexual mode of reproduction, A. areolatum and $A$. chailletii also reproduce sexually (Milgroom 1996; Otto 2003; Haag and Roze 2007; Houbraken et al. 2008). This is consistent with the notion that asexual reproduction allows for the maintenance of the symbiotic relationships of these fungi, while occasional sexual reproduction ensures their fitness and abiltiy to adapt to change. During such sexual interactions, polymorphism at the mat loci ensure compatibility among partners, which is the consequence of suppressed recombination that drives diversification of these loci. However, the predominantly asexual lifestyle of these fungi has apparently relaxed the need for positive selection to maintain additional mat alleles.

\section{ACKNOWLEDGEMENTS}

We thank the National Research Foundation (NRF), members of the Tree Pathology Cooperative Programme (TPCP) and the THRIP initiative of the Department of Trade and Industry (DTI), South Africa for financial support.

\section{REFERENCES}

Abascal F, Zardoya R, Posada D, 2005. ProtTest, selection of best-fit models of protein evolution. Bioinformatics 21: 2104-2105.

Barton NH, Charlesworth B, 1998. Why sex and recombination. Science 281: 1986-1990. 
Bernsel A, Viklund H, Hennerdal A, Elofsson A, 2009. TOPCONS, consensus prediction of membrane protein topology. Nucleic Acids Research (Webserver issue) 37: W465-8.

Boidin J, Lanquentin P, 1984. Le genre Amylostereum (Basidiomycetes) intercompatibilités partielles entre espèces allopartriques. Bulletin de la Société mycologique de France 100: 211236.

Brown AJ, Casselton LA, 2001. Mating in mushrooms: Increasing the chances but prolonging the affair. Trends in Genetics 7: 393-400.

Butlin R, 2006. Comment on "transitions to asexuality result in excess amino acid substitutions". Science 313: 1389b.

Chapela IH, Rehner SA, Schultz TR, Mueller UG, 1994. Evolutionary history of the symbiosis between fungus-growing ants and their fungi. Science 266: 1691-1694.

Ciampi MB, Gale LR, de Macedo Lemos EG, Ceresini PC, 2009. Distinctively variable sequence-based nuclear DNA markers for multilocus phylogeography of the soybean- and riceinfecting fungal pathogen Rhizoctonia solani AG-1 IA. Genetics and Molecular Biology 32: 840846.

Civetta AR, Singh S, 1998. Sex-related genes, directional sexual selection, and speciation. Molecular Biology and Evolution 15: 901-909.

Devier B, Aguileta G, Hood ME, Giraud T, 2009. Ancient trans-specific polymorphism at pheromone receptor genes in Basidiomycetes. Genetics 181: 209-223. 
Engh IB, Skrede I, Sætre G-P, Kauserud H, 2010. High variability in a mating type linked region in the dry rot fungus Serpula lacrymans caused by frequency-dependent selection? BMC Genetics 11: 64.

Garg S, Alam MT, Das MK, Dev V, Kumar A, Dash AP, Sharma YD, 2007. Sequence diversity and natural selection at domain I of the apical membrane antigen 1 among Indian Plasmodium falciparum populations. Malaria Journal 6: 154-163.

Glémin S, Bazin E, Charlesworth D, 2006. Impact of mating systems on patterns of sequence polymorphism in flowering plants. Proceedings of the Royal Society of London Series B 273: 3011-3019.

Gola S, Hegner J, Kothe E, 2000. Chimeric pheromone receptors in the basidiomycetes Schizophyllum commune. Fungal Genetics Biology 30: 191-196.

Gola S, Kothe E, 2003. The little difference, in vivo analysis of pheromone discrimination in Schizophyllum commune. Current Genetics 42: 276-283.

Guindon S, Gascuel O, 2003. A simple, fast and accurate algorithm to estimate large phylogenies by maximum likelihood. Systematic Biology 52: 696-704.

Haag CR, Roze D, 2007. Genetic load in sexual and asexual diploids, segregation, dominance and genetic drift. Genetics 176: 1663-1678.

Hall T, 1999. BioEdit, A user-friendly biological sequence alignment editor and analysis program for Windows 95/98/NT. Nucleic Acids Symposium Series 41: 95-98.

Hasegawa M, Kishino H, Yano T, 1985. Dating of human-ape splitting by a molecular clock of mitochondrial DNA. Journal of Molecular Evolution 22: 160-174. 
Haudry A, Cenci A, Guilhaumon C, Paux E, Santoni S, David J, Glémin S, 2008. Mating system and recombination affect molecular evolution in four Triticeae species. Genetic Research CAMB 90: 97-109.

Heitman J, Kronstad JW, Taylor JW, Casselton LA, 2007. Sex in Fungi: Molecular determination and evolutionary implications, ASM Press, Washington, DC.

Houbraken J, Varga J, Rico-Munoz E., Johnson S, Samson RA, 2008. Sexual Reproduction as the Cause of Heat Resistance in the Food Spoilage Fungus Byssochlamys spectabilis (Anamorph Paecilomyces variotii). Applied and Environmental Microbiology 74: 1613-1619.

Howe DK, Denver DR, 2008. Muller's ratchet and contemporary mutation in Caenorhabditis briggsae mitochondrial genome evolution. BMC Evolutionary Biology 8: 62.

Hsueh Y-P, Heitman J, 2008. Orchestration of sexual reproduction and virulence by the fungal mating-type locus. Current Opinion in Microbiology 11: 517-52.

Hudson RR, Kaplan NL, 1985. Statistical properties of the number of recombination events in the history of a sample of DNA sequences. Genetics 111: 147-164.

Hudson RR, Kreitman M, Aguade M, 1987. A test of neutral molecular evolution based on nucleotide data. Genetics 116: 153-159.

James TY, Kües U, Rehner SA, Vilgalys R, 2004a. Evolution of the gene encoding mitochondrial intermediate peptidase and its cosegregation with the A mating-type locus of mushroom fungi. Fungal Genetics Biology 41: 381-390.

James TY, Liou S-R, Vilgalys R, 2004b. The genetic structure and diversity of the A and B mating type genes from the tropical oyster mushroom, Pleurotus djamor. Fungal Genetics and Biology 41: 813-825. 
James TY, Moncalvo J-M, Li S, Vilgalys R, 2001. Polymorphism at the ribosomal DNA spacer and its relation to breeding structure of the widespread mushroom Schizophyllum commune. Genetics 157: 149-161.

James TY, Srivilai P, Kües U, Vilgalys R, 2006. Evolution of the bipolar mating system of the mushroom Coprinellus disseminatus from its tetrapolar ancestors involves loss of mating-typespecific pheromone receptor function. Genetics 172: 1877-1891.

Jany J-L, Pawlowska TE, 2010. Multinucleate spores contribute to evolutionary longevity of asexual Glomeromycota. The American Naturalist 175: 424-435.

Judson OP, Normark BB, 1996. Ancient asexual scandals. Tree 11: 41-46.

Kaltenpoth M, Goettler W, Koehler S, Strohm E, 2010. Life cycle and population dynamics of a protective insect symbiont reveal severe bottlenecks during vertical transmission. Evolutionary Ecology 24: 463-477.

Karlsson M, Nygren K, Johannesson H, 2008. The evolution of the pheromonal signal system and its potential role for reproductive isolation in heterothallic Neurospora. Molecular Biology and Evolution 25: 168-178.

Katoh K, Misawa K, Kuma K, Miyata T, 2002. MAFFT, a novel method for rapid multiple sequence alignment based on fast Fourier transform. Nucleic Acids Research 30: 3059-3066.

Kothe E, Gola S, Wendland J, 2003. Evolution of multispecific mating-type alleles for pheromone perception in the agaricomycetes fungi. Current Genetics 42: 268-275.

Kumar S, Dudley J, Nei M, Tamura K, 2008. MEGA, A biologist-centric software for evolutionary analysis of DNA and protein sequences. Briefings in Bioinformatics 9: 299-306. 
Le SQ, Gascuel O, 2008. An improved general amino acid replacement matrix. Molecular Biology and Evolution 25: 1307-1320.

Librado P, Rozas J, 2009. DnaSP v5, A software for comprehensive analysis of DNA polymorphism data. Bioinformatics 25: 1451-1452.

Lukens L, Yicunt H, May G, 1996. Correlation of genetic and physical maps at the a mating-type locus of Coprinus cinereus. Genetics 144: 1471-1477.

Madden JL, 1981. Egg and larval development in the woodwasp, Sirex noctilio. Forests Australian Journal of Botany 14: 25-30.

Marsh L, Neiman AM, Herskowitz I, 1991. Signal transduction during pheromone response in yeast. Annual Review of Cell and Developmental Biology 7: 699-728.

Martinez D, Challacombe J, Morgenstern I, David H, Schmoll M, Kubicek CP, Ferreira P, RuizDuenas FJ, Martinez AT, Kersten P, Hammel KE, Vanden Wymelenberg A, Gaskell J, Lindquist E, Sabat G, Sandra Splinter B, Larrondo LF, Canessa P, Vicuna R, Yadav J, Doddapaneni H, Subramanian V, Pisabarro AG, Lavín JL, Oguiza JA, Master E, Henrissat B, Coutinho PM, Harris P, Magnuson JK, Baker SE, Bruno K, Kenealy W, Hoegger PJ, Kües U, Ramaiya P, Lucas S, Salamov A, Shapiro H, Tu H, Chee CL, Misra M, Xie G, Teter S, Yaver D, James T, Mokrejs M, Pospisek M, Grigoriev IV, Brettin T, Rokhsar D, Berka R, Cullen D, 2009. Genome, transcriptome, and secretome analysis of wood decay fungus Postia placenta supports unique mechanisms of lignocellulose conversion. Proceedings of the National Academy of Sciences of the United States of America 106: 1954-1959. 
May GS, Badrane H, Vekemans X, 1999. The signature of balancing selection, Fungal mating compatibility gene evolution. Proceedings of the National Academy of Sciences of the United States of America 96: 9172-9177.

Menkis A, Jacobson DJ, Gustafsson T, Johannesson H, 2008. The mating-type chromosome in the filamentous ascomycete Neurospora tetrasperma represents a model for early evolution of sex chromosome. Plos Genetics 4: e1000030.

Metzger KJ, Thomas MA, 2010. Evidence of positive selection at codon sites localized in extracellular domains of mammalian $\mathrm{CC}$ motif chemokine receptor proteins. BMC Evolutionary Biology 10: 139.

Meyer D, Thomsen G, 2001. How selection shapes variation of the human major histocompatibility complex, a review. Annals of Human Genetics 65: 1-26.

Milgroom MG, 1996. Recombination and the multilocus structure of fungal populations. Annual Review of Phytopathology 34: 457-477.

Mira A, Moran NA, 2002. Estimating population size and transmission bottlenecks in maternally transmitted endosymbiotic bacteria. Microbial Ecology 44: 137-143.

Nei M, Li W-H, 1979. Mathematical model for studying genetic variation in terms of restriction endonucleases. Proceedings of the National Academy of Sciences of the United States of America 76: $5269-5273$.

Neiman M, Hehman G, Miller JT, Logsdon JM, Taylor DR, 2010. Accelerated mutation accumulation in asexual lineages of a freshwater snail. Molecular Biology and Evolution 27: 954-963. 
Niculita-Hirzel H, Labbé J, Kohler A, le Tacon F, Martin F, Sanders IR, Kües U, 2008. Gene organization of the mating type regions in the ectomycorrhizal fungus Laccaria bicolor reveals distinct evolution between the two mating type loci. New Phytologist 180: 329-342.

Nielsen C, Williams DW, Hajek AE, 2009. Putative source of the invasive Sirex noctilio fungal symbiont, Amylostereum areolatum, in the eastern United States and its association with native siricid woodwasps. Mycological Research 113: 1242-1253.

Otto SP, 2003. The Advantages of Segregation and the Evolution of Sex. Genetics 164: 10991118.

Paland S, Lynch M, 2006. Transitions to asexuality results in excess amino acid substitutions. Science 311: 990-992.

Posada D, 2008. jModelTest, Phylogenetic Model Averaging. Molecular Biology and Evolution 25: $1253-1256$.

Raudaskoski M, Kothe E, 2010. Basidiomycete mating type genes and pheromone signalling. Eukaryotic Cell 9: 847-859.

Reneke JE, Blumer KJ, Courchesne WE, Thorner J, 1988. The carboxy-terminal segment of the yeast $\alpha$-factor receptor is a regulatory domain. Cell 55: 221-234.

Riquelme M, Challen MP, Casselton LA, Brown AJ, 2005. The origin of multiple $b$ mating specificities in Coprinus cinereus. Genetics 170: 1105-1119.

Rispe C, Moran NA, 2000. Accumulation of deleterious mutations in endosymbionts, Muller's ratchet with two levels of selection. American Naturalist 156: 425-441. 
Ruggiero MV, Jacquemin B, Castric V, Vekemans X, 2008. Hitch-hiking to a locus under balancing selection, high sequence diversity and low pollution subdivision at the S-locus genomic region in Arabidopsis halleri. Genetic Research CAMB 90: 37-46.

Sambrook J, Fritsch EF, Maniatis T, 1989. Molecular cloning, a laboratory manual. Cold Spring Harbour Laboratory Press, New York.

Siebert PD, Chenchik A, Kellog DE, Lukyanov KA, Lukyanov SA, 1995. An improved PCR method for walking in uncloned genomic. DNA. Nucleic Acids Research 23: 1087-1088.

Slippers B, Coutinho TA, Wingfield BD, Wingfield MJ, 2003. A review of the genus Amylostereum and its association with woodwasps. South African Journal of Science 99: 70-74.

Slippers B, Wingfield BD, Coutinho TA, Wingfield MJ, 2002. DNA sequence and RFLP data reflect geographical spread and relationships of Amylostereum areolatum and its insect vectors. Molecular Ecology 11: 1845 -1854.

Slippers B, Wingfield MJ, Wingfield BD, Coutinho TA, 2000. Relationships among Amylostereum species associated with siricid woodwasps inferred from mitochondrial ribosomal DNA sequences. Mycologia 92: 955-963.

Slippers B, Wingfield MJ, Wingfield BD, Coutinho TA, 2001. Population structure and possible origin of Amylostereum areolatum in South Africa. Plant Pathology 50: 206-210.

Steenkamp ET, Wright J, Baldauf SL, 2006. The protistan origins of animals and fungi. Molecular Biology and Evolution 23: 93-106.

Swofford DL, 2000. PAUP*, phylogenetic analysis using parsimony (*and other methods), version 4.0b4a. Sinauer Associates, Sunderland, MA. 
Tabata M, Harrington TC, Chen W, Abe Y, 2000. Molecular phylogeny of species in the genera Amylostereum and Echinodontium. Mycoscience 41: 585-593.

Tamura K, Nei N, 1993. Estimation of the number of nucleotide substitutions in the control region of mitochondrial-DNA in humans and chimpanzees. Molecular Biology and Evolution 10: $512-526$.

Taylor JW, Jacobson DJ, Fisher MC, 1999. The evolution of asexual fungi, Reproduction, speciation and classification. Annual Review of Phytopathology 37: 197-246.

Thomsen IM, Koch J, 1999. Somatic compatibility in Amylostereum areolatum and A. chailletii as a consequence of symbiosis with Siricid. Mycological Research 103: 817-823.

Uyenoyama MK, 2005. Evolution under tight linkage to mating type. New Phytologist 165: 6370.

Vaillancourt LJ, Raudaskoski M, Specht CA, Raper CA, 1997. Multiple genes encoding pheromones and pheromone receptor define the B $\beta 1$ mating-type specificity in Schizophyllum commune. Genetics 146: 541-551.

Van der Nest MA, Slippers B, Steenkamp ET, de Vos L, van Zyl K, Stenlid J, Wingfield MJ, Wingfield BD, 2009. Genetic linkage map for Amylostereum areolatum reveals an association between vegetative growth and sexual and self recognition. Fungal Genetics and Biology 46: $632-641$.

Van der Nest MA, Slippers B, Stenlid J, Wilken PM, Vasaitis R, Wingfield MJ, Wingfield BD, 2008. Characterization of the systems governing sexual and self-recognition in the white rot agaricomycetes Amylostereum areolatum. Current Genetics 53: 323-336. 
Vasiliauskas R, Stenlid J, 1999. Vegetative compatibility groups of Amylostereum areolatum and A. chailletii from Sweden and Lithuania. Mycological Research 103: 824-829.

Vasiliauskas R, Stenlid J, Thomsen IM, Vasiliauskas R, Stenlid J, Thomsen IM, 1998. Clonality and genetic variation in Amylostereum areolatum and A. chailletii from northern Europe. New Phytologist 139: 751-758.

Vicoso B, Haddrill PR, Charlesworth, B, 2008. A multispecies approach for comparing sequence evolution of X-linked and autosomal sites in Drosophila. Genetic Research CAMB 90: 421-431.

Vieira J, Fonseca NA, Santos RAM, Habu T, Tao R, Vieira CP, 2008. The number, age, sharing and relatedness of S-locus. Genetic Research CAMB 90: 17-26.

Welch DBM, Meselson MS, 2001. Rates of nucleotide substitution in sexual and anciently asexual rotifers. Proceedings of the National Academy of Sciences of the United States of America 98: 6720-6724.

Wendland J, Kothe E, 1996. Allelic divergence of two mating type genes encoding the pheromone receptor $\mathrm{Bar} 1$ of $\mathrm{B} \alpha$ specificity in the basidiomycete Schizophyllum commune. FEMS Microbiology Letters 145: 451-455.

White TJ, Bruns T, Lee S, Taylor J, 1990. Amplification and direct sequencing of fungal ribosomal RNA genes for phylogenetics. In, Innis MA, Gelfand DH, Sninsky JJ, White TJ (eds), PCR Protocols. A Guide to Methods and Applications. Academic Press, San Diego, pp. 315-322.

Yang Z, 2007. PAML 4, phylogenetic analysis by maximum likelihood. Molecular Biology and Evolution 24: 1586-1591.

Yang Z, Nielson R, 1998. Synonymous and non-synonymous rate variation in nuclear genes of mammals. Journal of Molecular Evolution 46: 409-418. 
Yang Z, Nielson R, 2002. Codon-substitution models for detecting molecular adaptation at individual sites along specific lineages. Molecular Biology and Evolution 19: 908-917.

Yang Z, Nielson R, Goldman N, Pedersen AM, 2000. Codon-substitution models for heterogeneous selection pressure at amino acid sites. Genetics 155: 431-449.

Yang Z, Wong WSW, Nielsen R, 2005. Bayes empirical Bayes inference of amino acid sites under positive selection. Molecular Biology and Evolution 22: 1107-1118.

Zeyl C, Bell G, 1997. The advantage of sex in evolving yeast populations. Nature 388: 465-468.

Zhou XD, De Beer ZW, Ahumada R, Wingfield BD, Wingfield MJ, 2004. Ophiostomatoid fungi associated with two pine-infesting bark beetles from Chile. Fungal Diversity 15: 253-266. 


\section{Figures}

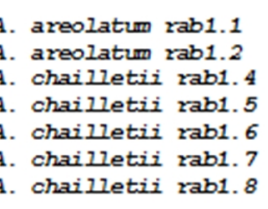

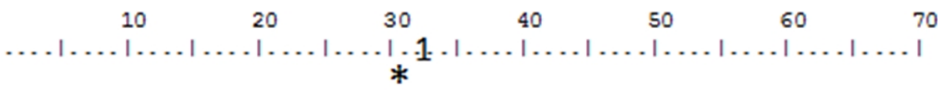

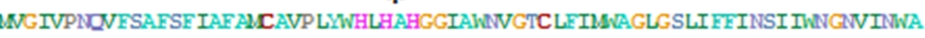

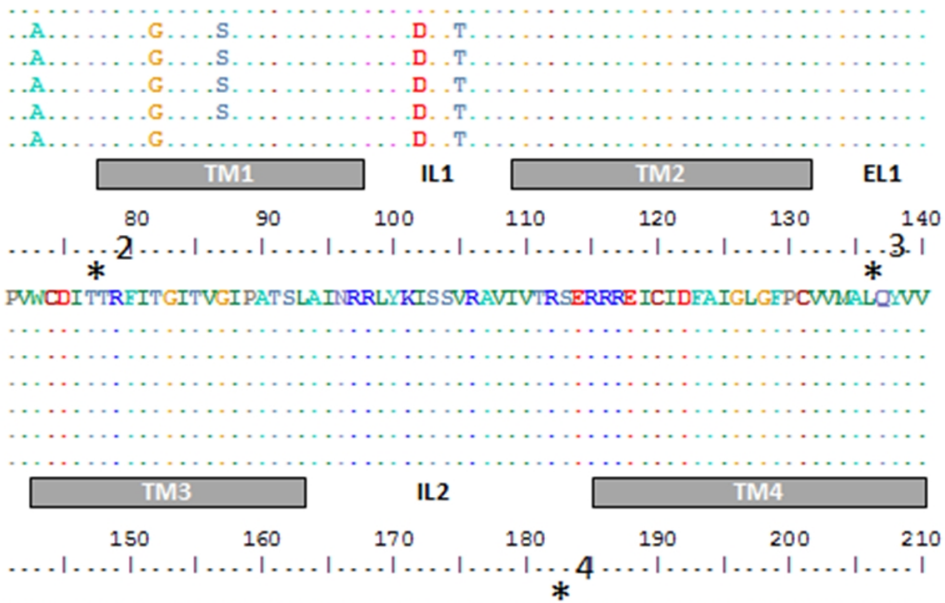

A. areolatum rab1.1

A. areolatum rab1.2

A. chailletii rab1.4

A. chailletii rab1.5

A. chailletii rab1.6

A. chailletii rab1.7

A. chailletii rab1.8

QGHRENIFEDIGCLPTTWNTH LAYVLVMAVPIVTGLISAGYCTAT TWNFYKTCRQLREVLSIHAGLNSSR

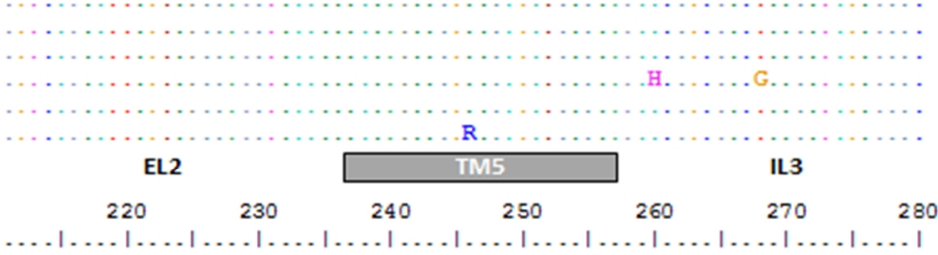

A. areolatum rab1.1

A. areolatum rab1.2

A. chailletii rab1.

A. chailletii rab1.5

A. chailletii rab1.6

A. chailletii rab1.7

A. chailletii rab1.8

IRLAR LASIELFATIPLASIVIWINSHESPVI PNKSWSDTHFDE SHVDVYPKVIWSSSS LFTIMTELOR

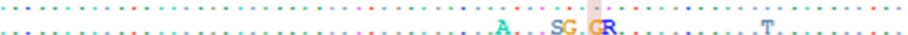

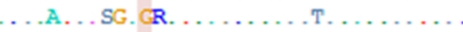

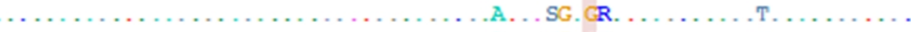

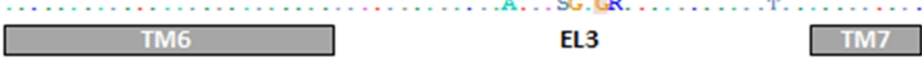

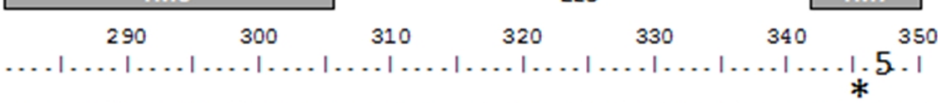

A. areolatum rab1.1 WLTIRCAFVEFF FFGEADEARKHYROAYTSVASRLGVTTSGSLESTAASPSESRRT TRRPRDRSARSS

A. areolatum rab1.2

A. chailletii rab1.

A. chailletii rab1.5

A. chailletii rab1.

A. chailletii rab1.7

A. chailletii rab1.8

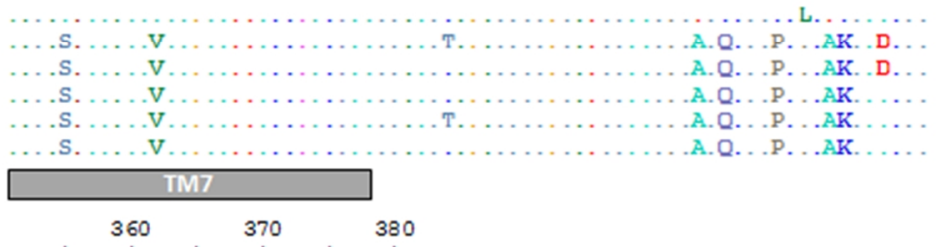

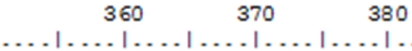

A. areolatum rab1.1 PSTSSOPRSPYPTFTQTSTTTRRRRRSSRP

A. areolatum rab1.2 N. ................... TM Transmembrane

A. areolatum rab1.2

A. chailletii rab1.5 …R...RSR.S.R.....AR.......L. IL Intracellularloop

A. chailletii rab1.6 ....R...RSR.S.R. ....R. ......L.

A. chailletii rab1.7 …R...RSR.S.R. ....R. ......L.

A. chailletii rab1.8 …R...RSR.S.R. ...AR. ..... L.

* Intron

Figure 1. The predicted amino acid sequences for the various alleles of the putative pheromone receptor rabl in A. areolatum and A. chailletii.

Protein domains were predicted with TOPCON (http://topcons.cbr.su.se) $)$ and codons under positive selections are indicated in the shaded boxes. 

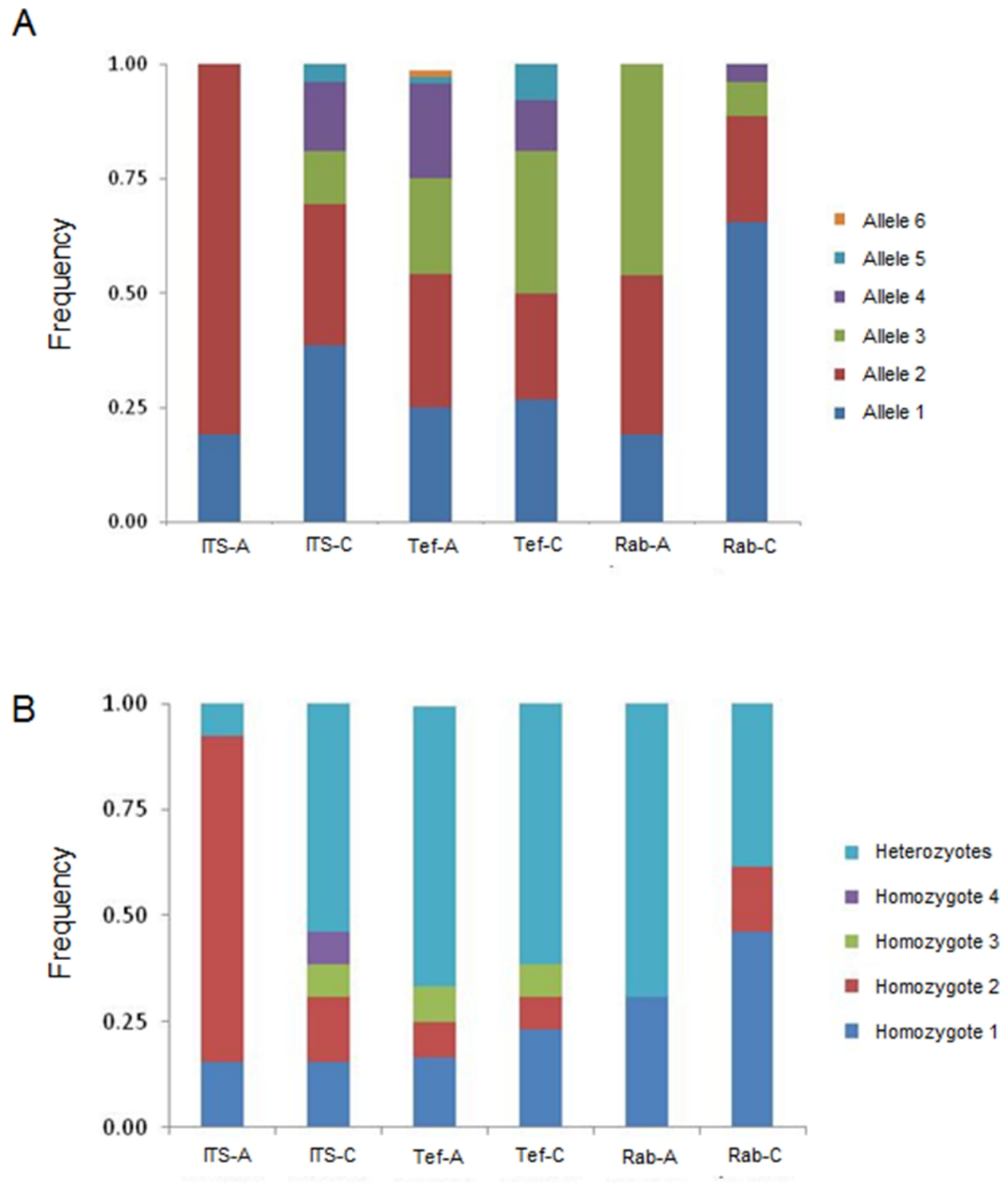

Figure 2. Stack histograms of allele frequencies (A) and genotype frequencies (B) at individual loci. ITS-A, ITS of A. areolatum; ITS-C, ITS of A. chailletii; Tef-A, Tef-1 $\alpha$ of $A$. areolatum; Tef-C, Tef-1 $\alpha$ of $A$. chailletii; Rab-A, rab1 of A areolatum; Rab-C, rab1 of $A$. chailletii. 


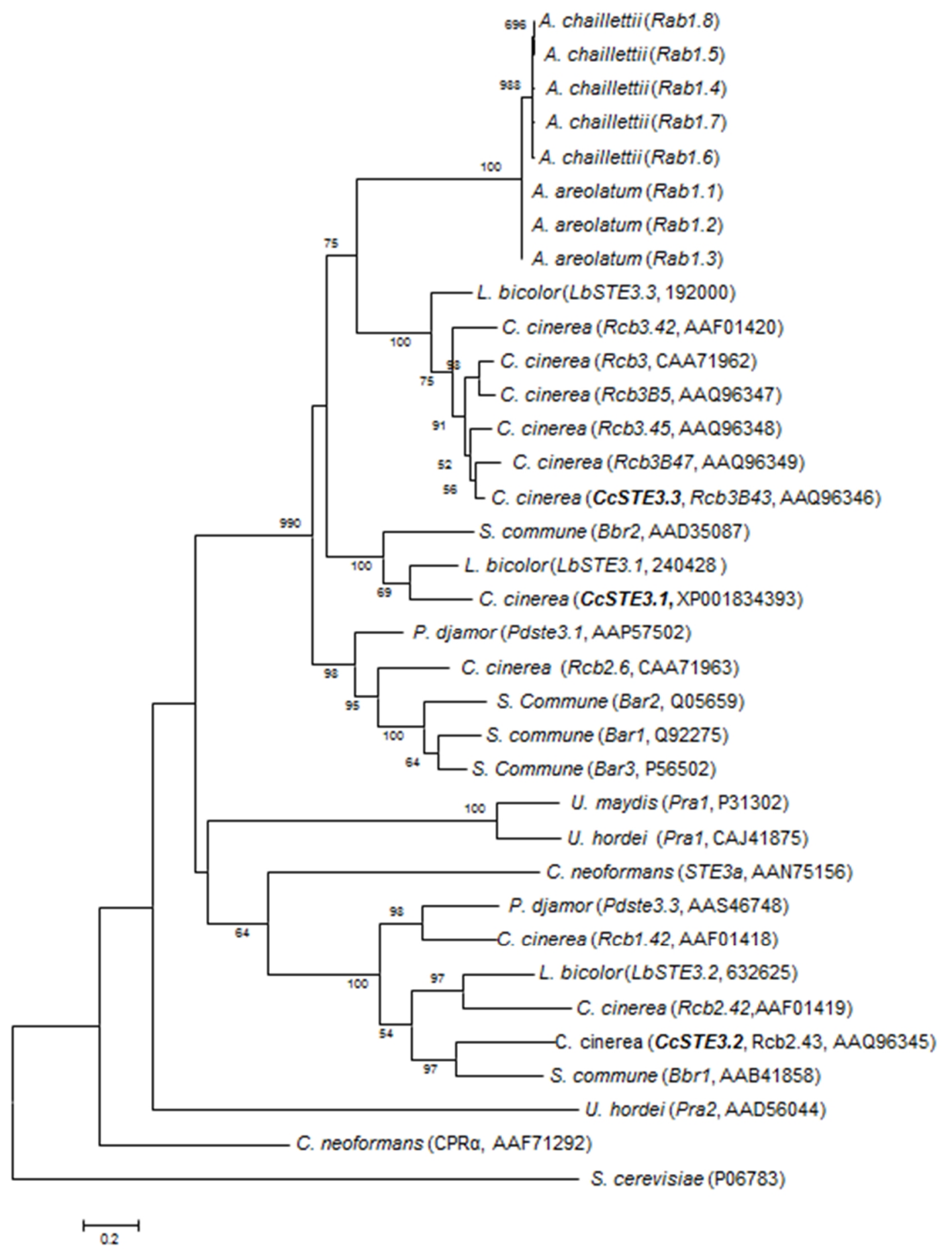

Figure 3. An amino acid-based maximum likelihood phylogeny of the pheromone receptors present in A. areolatum, A. chailletii and other Agaricomycetes. Percentage bootstrap (100 replicates) values greater than 50\% are shown below the tree branches. All of the $\mathrm{rabl}$ alleles in $\mathrm{A}$. areolatum and $A$. chailletii clustered in a species-specific manner, closely with the pheromone receptor genes CcSTE3.3 in C. cinerea and LbSte3.3 in L. bicolor (Niculita-Hirzel et al. 2008; Martinez et al. 2009). 


\section{TABLES}

Table 1. Heterozygosity tests ${ }^{\mathrm{a}}$ of the three genes present in the 13 heterokaryons each of $A$. areolatum and $A$. chailletii.

\begin{tabular}{llccc}
\hline Locus & Species & $\mathbf{A}^{\mathbf{b}}$ & $\mathbf{\Pi}^{\mathbf{c}}$ & $\boldsymbol{\pi}_{\mathbf{n}} / \boldsymbol{\pi}_{\mathbf{s}}{ }^{\mathbf{d}}$ \\
& & & & \\
\hline ITS & A. areolatum & 2 & 0.0004 & - \\
& A. chailletii & 5 & 0.0020 & - \\
& & & & \\
EF & A. areolatum & 5 & 0.0050 & $0.00^{*}$ \\
& A. chailletii & 5 & 0.0060 & $0.00^{*}$ \\
rab1 & A. areolatum & 3 & 0.0042 & $0.00^{*}$ \\
& A. chailletii & 4 & 0.0200 & $0.00^{*}$
\end{tabular}

\footnotetext{
${ }^{\text {a }}$ All estimates were determined with GENEPOP version 4. Significantly different values are indicated with an asterisk $(\mathrm{P}<0.05)$.

b Average number of alleles per locus.

${ }^{c}$ Mean number of pair-wise differences among sequences (Nei and Li, 1979).

${ }^{\mathrm{d}}$ Ratio of non-synonymous nucleotide variation to synonymous nucleotide variation.
} 
Table 2. Likelihood scores and parameter estimates for the site-specific models (Yang et al., 2000) evaluated in this study.

\begin{tabular}{|c|c|c|c|c|}
\hline Model $^{\text {a }}$ & ln Likelihood $^{\mathrm{b}}$ & $\begin{array}{l}\text { Sites with } \mathrm{P}(\omega>1) \\
>0.95 \mathrm{NEB}^{*}\end{array}$ & $d N / d S^{\mathrm{c}}$ & Estimates of parameters ${ }^{\mathrm{d}}$ \\
\hline M0 (One-ratio) & -2100.89 & n.a. & 0.0682 & $\omega_{1}=0.0682$ \\
\hline M1 (Neutral) & -2096.32 & n.a. & 0.1321 & $\omega_{0}=0.01309 p_{0}=0.89171 \omega_{1}=1 \quad p_{1}=0.10829$ \\
\hline M2 (Selection) & -2096.32 & - & 0.1200 & $\begin{array}{l}\omega_{0}=0.01308 p_{0}=0.89171 \\
\omega_{1}=1 \quad p_{1}=0.04405\end{array}$ \\
\hline M3(Discrete) & -2096.14 & n.a. & 0.1283 & $\begin{array}{l}\omega_{0}=0.00000 p_{0}=0.81906 \omega_{1}=0.48426 \\
p_{I}=0.16723 \omega_{2}=3.44796 p_{2}=0.01371\end{array}$ \\
\hline M5 (Gamma) & -2096.31 & $\begin{array}{l}256 \mathrm{G}^{*} \\
372 \mathrm{~A}^{*}\end{array}$ & 0.1194 & $a=0.06624 b=0.36890$ \\
\hline M6 (Double gamma) & -2096.14 & $\begin{array}{l}256 \mathrm{G}^{*} \\
372 \mathrm{~A}^{*}\end{array}$ & 0.1283 & $\begin{array}{l}p_{0}=0.89259 a_{0}=0.04008 b_{0}=1.13382 \\
p_{I}=0.10741 \quad a_{I}=2.73793 b_{l}=2.73793\end{array}$ \\
\hline M7 ( $\beta$ distribution) & -2096.30 & n.a. & 0.1183 & $p=0.01742 \quad q=0.11677$ \\
\hline M8 ( $\beta+$ positive selection $)$ & -2096.30 & & 0.1260 & $\begin{array}{l}p_{0}=0.96972 p=0.05439 q=0.44414 \\
\omega=1.000\end{array}$ \\
\hline
\end{tabular}

${ }^{a}$ Site-specific models implemented in the CODEML program in PAML version 3.14 package (Yang and Nielson, 2002).

${ }^{\mathrm{b}}$ Model likelihoods used for calculating statistical significance with likelihood ratio tests (LRT), which entailed analysis of the $\chi^{2}$ distribution of $2 \Delta \ln ($ i.e., twice the log likelihood difference between the two models) for the different models (Yang and Nielson, 1998).

c The non-synonymous $(d N)$ /synonymous $(d S)$ substitution rate ratio (Yang and Nielson, 1998).

${ }^{d}$ Parameters estimated for each model according to those proposed by Yang (2007).

${ }^{*} \mathrm{NEB}=$ Naive empirical Bayes 
Table 3. Results of the recombination tests as determined with DnaSP 5.10 (Librado and Rozas, 2009).

\begin{tabular}{|c|c|c|c|c|c|c|}
\hline \multirow[b]{2}{*}{ Genes } & \multirow[b]{2}{*}{ Species } & \multirow[b]{2}{*}{$R^{a}$} & \multirow[b]{2}{*}{$R_{M}^{b}$} & \multicolumn{3}{|c|}{ Coalescence simulations $^{c}$} \\
\hline & & & & $\begin{array}{l}\text { Confidence } \\
\text { interval }^{d}\end{array}$ & $\begin{array}{c}P \\
\left(R_{M} \leq \text { observed } R_{\mathrm{M}}\right)^{e}\end{array}$ & $\operatorname{Avg} R_{M}^{f}$ \\
\hline \multirow[t]{2}{*}{$R a b 1$} & A. areolatum & 0.0010 & 1.0000 & $0.0,0.0$ & 2.8190 & 0.0002 \\
\hline & A. chailletii & 0.0007 & 0.9940 & $0.0,1.0$ & 0.9944 & 0.1709 \\
\hline \multirow[t]{2}{*}{ ITS } & A. areolatum & 0.0010 & 0.0001 & $0.0,0.0$ & 2.8068 & 0.0000 \\
\hline & A. chailletii & 0.5000 & 0.9920 & $0.0,1.0$ & 4.2558 & 0.1728 \\
\hline \multirow[t]{2}{*}{ Tef- $1 \alpha$} & A. areolatum & 7.0990 & 0.6417 & $0.0,2.0$ & 1.2937 & 0.3911 \\
\hline & A. chailletii & 0.0200 & 0.9995 & $0.0,0.0$ & 1.5337 & 0.0005 \\
\hline
\end{tabular}

${ }^{a}$ Estimate of the population recombination parameter $R$ excluding alignment gaps and haploid corrections.

${ }^{b}$ The observed minimum number of recombination events in the data.

${ }^{c}$ Neutral coalescence simulations given the number of segregating sites, with an intermediate level of recombination and 10000 replications.

${ }^{d}$ The confidence interval (lower limit, upper limit) for $R_{\mathrm{M}}$.

${ }^{e}$ The probability that $R_{\mathrm{M}}$ is less than or equal to the observed $R \mathrm{M}$.

${ }^{f}$ The average value of $R_{\mathrm{M}}$. 

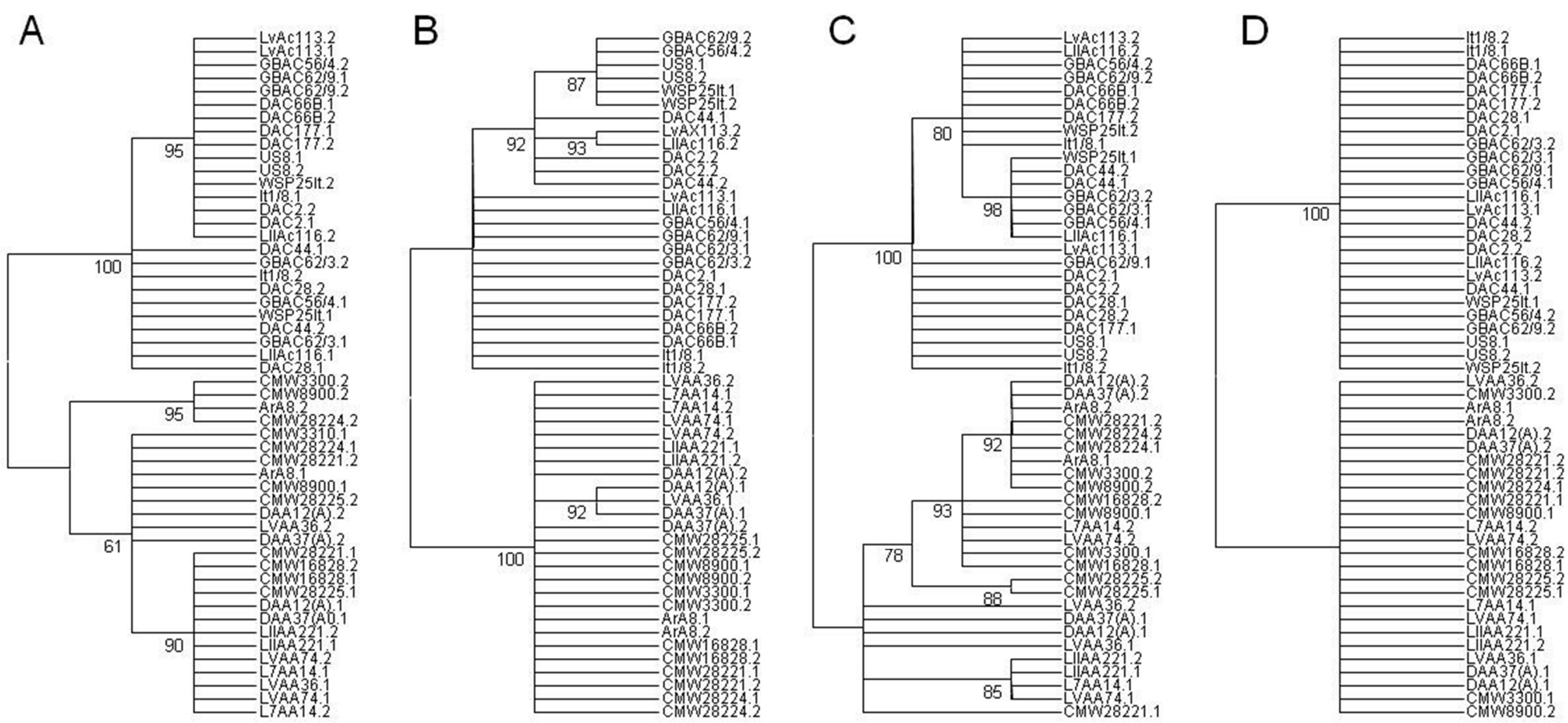

Supplementary Figure 1. Maximum likelihood gene trees based on the rab1 (A), ITS (B) and Tef-1 $\alpha$ (C) sequences for the isolates of $A$. areolatum and A. chailletii included in this study. The strict consensus (D) for the three trees was inferred in MEGA. For heterozygotic isolates, the alleles are indicated by the digits 1 or 2 following an isolate number. Percentage bootstrap (100 replicates) values greater than $50 \%$ are shown below the tree branches. 
Supplementary Table 1 . The nucleotide polymorphisms rabl sequences in the $25 \mathrm{~A}$. areolatum isolates.

\begin{tabular}{|c|c|c|c|c|c|c|c|c|c|c|}
\hline \multirow{2}{*}{$\begin{array}{l}\text { Isolate } \\
\text { number }\end{array}$} & \multirow[t]{2}{*}{ Collector } & \multirow{2}{*}{$\begin{array}{l}\text { Geographic } \\
\text { origin }\end{array}$} & \multicolumn{8}{|c|}{ Nucleotide polymorphisms ${ }^{\mathrm{a}}$} \\
\hline & & & 62 & 74 & 78 & 89 & 91 & 95 & 150 & 159 \\
\hline & & & * & * & $*$ & $*$ & $*$ & $*$ & & \\
\hline \multirow[t]{2}{*}{ CMW16848 } & R. Vasaitis & Austria & C & $T$ & G & C & G & $\mathbf{T}$ & A & A \\
\hline & & & $\mathrm{C}$ & $\mathrm{T}$ & G & $\mathrm{T}$ & $\mathrm{G}$ & $\mathrm{T}$ & A & A \\
\hline \multirow[t]{2}{*}{ LIIAA5(LK) } & R. Vasaitis & Lithuania & $\underline{T}$ & $\underline{\mathbf{C}}$ & $\underline{\mathbf{A}}$ & $\underline{\mathbf{T}}$ & $\underline{\mathbf{T}}$ & $\underline{\mathbf{G}}$ & $\underline{\mathbf{G}}$ & $\underline{\mathbf{G}}$ \\
\hline & & & $\underline{T}$ & $\underline{\mathbf{C}}$ & $\underline{\mathbf{A}}$ & $\underline{\mathbf{T}}$ & $\underline{\mathbf{T}}$ & $\underline{\mathbf{G}}$ & $\underline{\mathbf{G}}$ & $\underline{\mathbf{G}}$ \\
\hline \multirow[t]{2}{*}{ LVAA36 } & R. Vasaitis & Sweden & $\mathrm{C}$ & $\mathbf{T}$ & G & $\mathbf{C}$ & G & $\mathbf{T}$ & $\mathbf{A}$ & $\mathbf{A}$ \\
\hline & & & $\mathrm{C}$ & $\mathrm{T}$ & $\mathrm{G}$ & $\mathrm{T}$ & $\mathrm{G}$ & $\mathrm{T}$ & A & A \\
\hline \multirow[t]{2}{*}{ L7AA14 } & R. Vasaitis & Denmark & $\mathrm{C}$ & $\mathrm{T}$ & G & $\mathrm{T}$ & G & $\mathrm{T}$ & A & $\mathrm{A}$ \\
\hline & & & $\mathrm{C}$ & $\mathrm{T}$ & G & $\mathrm{T}$ & G & $\mathrm{T}$ & A & A \\
\hline \multirow[t]{2}{*}{ LVAA74 } & R. Vasaitis & Lithuania & $\mathrm{C}$ & $\mathrm{T}$ & G & $\mathrm{T}$ & $\mathrm{G}$ & $\mathrm{T}$ & A & A \\
\hline & & & $\mathrm{C}$ & $\mathrm{T}$ & G & $\mathrm{T}$ & G & $\mathrm{T}$ & A & $\mathrm{A}$ \\
\hline \multirow[t]{2}{*}{ LIIAA221 } & R. Vasaitis & Lithuania & $\mathrm{C}$ & $\mathrm{T}$ & G & $\mathrm{T}$ & G & $\mathrm{T}$ & A & $\mathrm{A}$ \\
\hline & & & $\mathrm{C}$ & $\mathrm{T}$ & G & $\mathrm{T}$ & G & $\mathrm{T}$ & A & A \\
\hline \multirow[t]{2}{*}{ DAA12(A) } & I. Thomsen & Denmark & $\mathrm{C}$ & $\mathbf{T}$ & G & $\mathrm{C}$ & G & $\mathbf{T}$ & $\mathbf{A}$ & $\mathbf{A}$ \\
\hline & & & $\mathrm{C}$ & $\mathrm{T}$ & G & $\mathrm{T}$ & G & $\mathrm{T}$ & A & $\mathrm{A}$ \\
\hline \multirow[t]{2}{*}{ DAA37(A) } & I. Thomsen & Denmark & $\mathrm{C}$ & $\mathbf{T}$ & G & $\mathrm{C}$ & G & $\mathbf{T}$ & $\mathbf{A}$ & $\mathbf{A}$ \\
\hline & & & $\mathrm{C}$ & $\mathrm{T}$ & G & $\mathrm{T}$ & G & $\mathrm{T}$ & A & A \\
\hline \multirow[t]{2}{*}{ CMW28225 } & I. Thomsen & Denmark & C & $\mathbf{T}$ & G & C & G & $\mathbf{T}$ & $\mathbf{A}$ & $\mathbf{A}$ \\
\hline & & & $\mathrm{C}$ & $\mathrm{T}$ & G & $\mathrm{T}$ & G & $\mathrm{T}$ & A & A \\
\hline \multirow[t]{2}{*}{ DAA547(B) } & I. Thomsen & Denmark & C & $\mathbf{T}$ & G & C & G & $\mathbf{T}$ & A & A \\
\hline & & & $\mathrm{C}$ & $\mathbf{T}$ & G & $\mathbf{C}$ & G & $\mathbf{T}$ & $\mathbf{A}$ & $\mathbf{A}$ \\
\hline \multirow[t]{2}{*}{ CMW4644 } & B. Slippers & Australia & $\mathrm{C}$ & $\mathrm{T}$ & G & $\mathrm{T}$ & G & $\mathrm{T}$ & A & A \\
\hline & & & $\mathrm{C}$ & $\mathrm{T}$ & G & $\mathrm{T}$ & G & $\mathrm{T}$ & A & A \\
\hline
\end{tabular}




\begin{tabular}{|c|c|c|c|c|c|c|c|c|c|c|}
\hline \multirow{2}{*}{ CMW8898 } & B. Slippers & Brazil & $\mathrm{C}$ & $\mathbf{T}$ & G & $\mathbf{C}$ & G & $\mathbf{T}$ & $\mathbf{A}$ & $\mathbf{A}$ \\
\hline & & & $\mathrm{C}$ & $\mathrm{T}$ & $\mathrm{G}$ & $\mathrm{T}$ & G & $\mathrm{T}$ & A & A \\
\hline \multirow[t]{2}{*}{ CMW8900 } & B. Slippers & South Africa & $\underline{\mathbf{T}}$ & $\underline{\mathrm{C}}$ & $\underline{\mathbf{A}}$ & $\underline{T}$ & $\underline{T}$ & $\underline{\mathbf{G}}$ & $\underline{\mathbf{G}}$ & $\underline{\mathbf{G}}$ \\
\hline & & & $\mathrm{C}$ & $\mathbf{T}$ & G & $\mathrm{C}$ & G & $\mathbf{T}$ & $\mathbf{A}$ & $\mathbf{A}$ \\
\hline \multirow[t]{2}{*}{ CMW3300 } & B. Slippers & New Zealand & $\underline{\mathbf{T}}$ & $\underline{\mathrm{C}}$ & $\underline{\mathbf{A}}$ & $\underline{\mathbf{T}}$ & $\underline{T}$ & $\underline{\mathbf{G}}$ & $\underline{\mathbf{G}}$ & $\underline{\mathbf{G}}$ \\
\hline & & & $\mathrm{C}$ & $\mathbf{T}$ & G & $\mathrm{C}$ & G & $\mathbf{T}$ & $\mathbf{A}$ & $\mathbf{A}$ \\
\hline \multirow[t]{2}{*}{ CMW3310 } & G.B. Rawlings & France & $\mathrm{C}$ & $\mathrm{T}$ & G & $\mathrm{T}$ & G & $\mathrm{T}$ & A & A \\
\hline & & & $\mathrm{C}$ & $\mathrm{T}$ & $\mathrm{G}$ & $\mathrm{T}$ & $\mathrm{G}$ & $\mathrm{T}$ & A & A \\
\hline \multirow[t]{2}{*}{ ArA8 } & B. Slippers & Argentina & $\underline{\mathbf{T}}$ & $\underline{\mathbf{C}}$ & $\underline{\mathbf{A}}$ & $\underline{\mathbf{T}}$ & $\underline{\mathbf{T}}$ & $\underline{\mathbf{G}}$ & $\underline{\mathbf{G}}$ & $\underline{\mathbf{G}}$ \\
\hline & & & $\mathbf{C}$ & $\mathbf{T}$ & $\mathbf{G}$ & $\mathrm{C}$ & G & $\mathbf{T}$ & $\mathbf{A}$ & $\mathbf{A}$ \\
\hline \multirow[t]{2}{*}{ CMW16828 } & B. Slippers & Austria & $\mathrm{C}$ & $\mathrm{T}$ & G & $\mathrm{T}$ & G & $\mathrm{T}$ & A & A \\
\hline & & & $\mathrm{C}$ & $\mathrm{T}$ & G & $\mathrm{T}$ & G & $\mathrm{T}$ & A & A \\
\hline \multirow[t]{2}{*}{ At-II-28 } & B. Slippers & Austria & $\mathrm{C}$ & $\mathrm{T}$ & G & $\mathrm{T}$ & G & $\mathrm{T}$ & A & A \\
\hline & & & $\mathrm{C}$ & $\mathrm{T}$ & $\mathrm{G}$ & $\mathrm{T}$ & $\mathrm{G}$ & $\mathrm{T}$ & A & A \\
\hline \multirow[t]{2}{*}{ CMW28221 } & H. Solheim & Norway & $\mathrm{C}$ & $\mathrm{T}$ & G & $\mathrm{T}$ & G & $\mathrm{T}$ & A & A \\
\hline & & & C & $\mathbf{T}$ & G & C & G & $T$ & $\mathbf{A}$ & $\mathbf{A}$ \\
\hline \multirow[t]{2}{*}{ DAA547B } & H. Solheim & Norway & $\mathrm{C}$ & $\mathrm{T}$ & $\mathrm{G}$ & $\mathrm{T}$ & $\mathrm{G}$ & $\mathrm{T}$ & A & A \\
\hline & & & $\mathrm{C}$ & $\mathrm{T}$ & $\mathrm{G}$ & $\mathrm{T}$ & $\mathrm{G}$ & $\mathrm{T}$ & A & A \\
\hline \multirow[t]{2}{*}{ CMW28223 } & O. Holgenrieder & Switzerland & $\underline{\mathbf{T}}$ & $\underline{\mathbf{C}}$ & $\underline{\mathbf{A}}$ & $\underline{\mathbf{T}}$ & $\underline{\mathbf{T}}$ & $\underline{\mathbf{G}}$ & $\underline{\mathbf{G}}$ & $\underline{\mathbf{G}}$ \\
\hline & & & $\mathrm{C}$ & $\mathrm{T}$ & G & $\mathrm{T}$ & G & $\mathrm{T}$ & A & A \\
\hline \multirow[t]{2}{*}{ CMW28224 } & O. Holgenrieder & Switzerland & $\underline{T}$ & $\underline{\mathbf{C}}$ & $\underline{\mathbf{A}}$ & $\underline{T}$ & $\underline{T}$ & $\underline{\mathbf{G}}$ & $\underline{\mathbf{G}}$ & $\underline{\mathbf{G}}$ \\
\hline & & & $\mathrm{C}$ & $\mathbf{T}$ & $\mathbf{G}$ & $\mathbf{C}$ & $\mathbf{G}$ & $\mathbf{T}$ & $\mathbf{A}$ & $\mathbf{A}$ \\
\hline \multirow[t]{2}{*}{ AtII-18 } & B. Slippers & Austria & $\mathrm{C}$ & $\mathrm{T}$ & $\mathrm{G}$ & $\mathrm{T}$ & $\mathrm{G}$ & $\mathrm{T}$ & A & A \\
\hline & & & $\mathrm{C}$ & $\mathrm{T}$ & $\mathrm{G}$ & $\mathrm{T}$ & $\mathrm{G}$ & $\mathrm{T}$ & $\mathrm{A}$ & A \\
\hline \multirow[t]{2}{*}{ At-23 } & B. Slippers & Austria & $\mathrm{C}$ & $\mathrm{T}$ & $\mathrm{G}$ & $\mathrm{T}$ & $\mathrm{G}$ & $\mathrm{T}$ & A & A \\
\hline & & & $\mathrm{C}$ & $\mathrm{T}$ & G & $\mathrm{T}$ & G & $\mathrm{T}$ & A & A \\
\hline \multirow[t]{2}{*}{ AtIII-4 } & B. Slippers & Austria & $\mathbf{C}$ & $\mathbf{T}$ & G & $\mathbf{C}$ & $\mathbf{G}$ & $\mathbf{T}$ & $\mathbf{A}$ & $\mathbf{A}$ \\
\hline & & & $\mathrm{C}$ & $\mathrm{T}$ & $\mathrm{G}$ & $\mathrm{T}$ & $\mathrm{G}$ & $\mathrm{T}$ & A & A \\
\hline
\end{tabular}

${ }^{\text {a }}$ Polymorphisms located in introns are indicated with asterisks. 
Supplementary Table 2. The nucleotide polymorphisms rabl sequences in the $25 \mathrm{~A}$. chailletii isolates.

\begin{tabular}{|c|c|c|c|c|c|c|c|c|}
\hline \multirow{2}{*}{$\begin{array}{l}\text { Isolate } \\
\text { number }\end{array}$} & \multirow[t]{2}{*}{ Collector } & \multirow{2}{*}{$\begin{array}{c}\text { Geographic } \\
\text { origin }\end{array}$} & \multicolumn{6}{|c|}{ Nucleotide polymorphisms } \\
\hline & & & 87 & 92 & 103 & 130 & 139 & 160 \\
\hline \multirow{3}{*}{ A.ch.536 } & & & $*$ & $*$ & $*$ & & & \\
\hline & R. Vasaitis & Sweden & $\mathrm{C}$ & $\mathbf{T}$ & C & C & $\mathbf{T}$ & $\mathrm{C}$ \\
\hline & & & $\mathrm{C}$ & $\mathbf{T}$ & C & C & $\mathbf{T}$ & C \\
\hline \multirow[t]{2}{*}{ LvAc22C } & R. Vasaitis & Lithuania & $\mathrm{C}$ & $\mathrm{T}$ & $\mathrm{C}$ & $\mathrm{C}$ & $\mathrm{C}$ & $\mathrm{C}$ \\
\hline & & & $\mathrm{C}$ & $\mathrm{T}$ & $\mathrm{C}$ & $\mathrm{C}$ & $\mathrm{C}$ & $\mathrm{C}$ \\
\hline \multirow[t]{2}{*}{ LvAc113 } & R. Vasaitis & Lithuania & $\mathrm{C}$ & $\mathrm{T}$ & $\mathrm{C}$ & $\mathrm{C}$ & $\mathrm{C}$ & $\mathrm{C}$ \\
\hline & & & $\mathrm{C}$ & $\mathrm{T}$ & $\mathrm{C}$ & $\mathrm{C}$ & $\mathrm{C}$ & $\mathrm{C}$ \\
\hline \multirow[t]{2}{*}{ LIIAc1 16} & R. Vasaitis & Lithuania & $\mathrm{C}$ & $\mathrm{T}$ & $\mathrm{C}$ & $\mathrm{C}$ & $\mathrm{C}$ & $\mathrm{C}$ \\
\hline & & & $\mathrm{C}$ & $\mathrm{T}$ & $\mathrm{C}$ & $\mathrm{C}$ & $\mathrm{C}$ & $\mathrm{C}$ \\
\hline \multirow[t]{2}{*}{ GBAC56.4 } & D. Redfern & UK & $\mathrm{C}$ & $\mathrm{T}$ & $\mathrm{C}$ & $\mathrm{C}$ & $\mathrm{C}$ & $\mathrm{C}$ \\
\hline & & & $\mathrm{C}$ & $\mathrm{T}$ & $\mathrm{C}$ & $\mathrm{C}$ & $\mathrm{C}$ & $\mathrm{C}$ \\
\hline \multirow[t]{2}{*}{ GBAC62.11 } & D. Redfern & UK & $\mathrm{C}$ & $\mathbf{T}$ & C & C & $\mathbf{T}$ & C \\
\hline & & & $\mathrm{C}$ & $\mathrm{T}$ & $\mathrm{C}$ & $\mathrm{C}$ & $\mathrm{C}$ & $\mathrm{C}$ \\
\hline \multirow[t]{2}{*}{ GBAC62.9 } & D. Redfern & UK & $\mathrm{C}$ & $\mathrm{T}$ & $\mathrm{C}$ & $\mathrm{C}$ & $\mathrm{C}$ & $\mathrm{C}$ \\
\hline & & & $\mathrm{C}$ & $\mathrm{T}$ & $\mathrm{C}$ & $\mathrm{C}$ & $\mathrm{C}$ & $\mathrm{C}$ \\
\hline \multirow[t]{2}{*}{ GB AC62.3 } & D. Redfern & UK & $\mathrm{C}$ & $\mathbf{T}$ & C & C & $\mathbf{T}$ & C \\
\hline & & & $\mathrm{C}$ & $\mathrm{T}$ & $\mathrm{C}$ & $\mathrm{C}$ & $\mathrm{C}$ & $\mathrm{C}$ \\
\hline \multirow[t]{2}{*}{ GBAC62 } & D. Redfern & UK & $\mathrm{C}$ & $\mathrm{T}$ & $\mathrm{C}$ & $\mathrm{C}$ & $\mathrm{C}$ & $\mathrm{C}$ \\
\hline & & & $\mathrm{C}$ & $\mathrm{T}$ & $\mathrm{C}$ & $\mathrm{C}$ & $\mathrm{C}$ & $\mathrm{C}$ \\
\hline \multirow[t]{2}{*}{ DAC2 } & I. Thomsen & Denmark & $\mathrm{C}$ & $\mathrm{T}$ & $\mathrm{C}$ & $\mathrm{C}$ & $\mathrm{C}$ & $\mathrm{C}$ \\
\hline & & & $\mathrm{C}$ & $\mathrm{T}$ & $\mathrm{C}$ & $\mathrm{C}$ & $\mathrm{C}$ & $\mathrm{C}$ \\
\hline \multirow[t]{2}{*}{ DAC7 } & I. Thomsen & Denmark & $\mathrm{C}$ & $\mathrm{T}$ & $\mathrm{C}$ & $\mathrm{C}$ & $\mathrm{C}$ & $\mathrm{C}$ \\
\hline & & & $\mathrm{C}$ & $\mathrm{T}$ & $\mathrm{C}$ & $\mathrm{C}$ & $\mathrm{C}$ & $\mathrm{C}$ \\
\hline \multirow[t]{2}{*}{ DAC28 } & I. Thomsen & Denmark & $\mathrm{C}$ & $\mathrm{T}$ & $\mathrm{C}$ & $\mathrm{C}$ & $\mathrm{C}$ & $\mathrm{C}$ \\
\hline & & & $\mathrm{C}$ & $\mathrm{T}$ & $\mathrm{C}$ & $\mathrm{C}$ & $\mathrm{C}$ & $\mathrm{C}$ \\
\hline
\end{tabular}




\begin{tabular}{|c|c|c|c|c|c|c|c|c|}
\hline \multirow[t]{2}{*}{ DAC35 } & I. Thomsen & Denmark & $\mathrm{C}$ & $\mathbf{T}$ & $\mathbf{C}$ & $\mathbf{C}$ & $\mathbf{T}$ & C \\
\hline & & & $\mathrm{C}$ & $\mathrm{T}$ & $\mathrm{C}$ & $\mathrm{C}$ & $\mathrm{C}$ & $\mathrm{C}$ \\
\hline \multirow[t]{2}{*}{ DAC44 } & I. Thomsen & Denmark & $\mathrm{C}$ & $\mathrm{T}$ & $\mathrm{C}$ & C & C & $\mathrm{C}$ \\
\hline & & & $\mathrm{C}$ & $\mathrm{T}$ & $\mathrm{C}$ & $\mathrm{C}$ & $\mathrm{C}$ & $\mathrm{C}$ \\
\hline \multirow[t]{2}{*}{ DAC66B } & I. Thomsen & Denmark & $\mathrm{C}$ & $\mathrm{T}$ & $\mathrm{C}$ & $\mathrm{C}$ & $\mathrm{C}$ & $\mathrm{C}$ \\
\hline & & & $\mathrm{C}$ & $\mathrm{T}$ & $\mathrm{C}$ & $\mathrm{C}$ & $\mathrm{C}$ & $\mathrm{C}$ \\
\hline \multirow[t]{2}{*}{ DAC66D } & I. Thomsen & Denmark & $\mathrm{C}$ & $\mathbf{T}$ & $\mathrm{C}$ & $\mathrm{C}$ & $\mathbf{T}$ & C \\
\hline & & & $\mathrm{C}$ & $\mathrm{T}$ & $\mathrm{C}$ & $\mathrm{C}$ & $\mathrm{C}$ & $\mathrm{C}$ \\
\hline \multirow[t]{2}{*}{ DAC78 } & I. Thomsen & Denmark & $\mathrm{C}$ & $\mathrm{T}$ & $\mathrm{C}$ & $\mathrm{C}$ & $\mathrm{C}$ & $\mathrm{C}$ \\
\hline & & & $\mathrm{C}$ & $\mathrm{T}$ & $\mathrm{C}$ & $\mathrm{C}$ & $\mathrm{C}$ & $\mathrm{C}$ \\
\hline \multirow[t]{2}{*}{ DAC177 } & I. Thomsen & Denmark & $\mathrm{C}$ & $\mathrm{T}$ & $\mathrm{C}$ & $\mathrm{C}$ & $\mathrm{C}$ & $\mathrm{C}$ \\
\hline & & & $\mathrm{C}$ & $\mathrm{T}$ & $\mathrm{C}$ & $\mathrm{C}$ & $\mathrm{C}$ & $\mathrm{C}$ \\
\hline \multirow[t]{2}{*}{ DAC1941 } & I. Thomsen & Denmark & C & $\mathbf{T}$ & C & C & $\mathbf{T}$ & C \\
\hline & & & $\mathrm{C}$ & $\mathrm{T}$ & $\mathrm{C}$ & $\mathrm{C}$ & $\mathrm{C}$ & $\mathrm{C}$ \\
\hline \multirow[t]{2}{*}{ US1 } & H.H. Burdsall & US & $\underline{\mathbf{A}}$ & $\underline{\mathrm{C}}$ & $\underline{\mathbf{G}}$ & $\underline{T}$ & $\underline{\mathrm{C}}$ & $\underline{\mathbf{T}}$ \\
\hline & & & $\mathrm{C}$ & $\mathrm{T}$ & $\mathrm{C}$ & $\mathrm{C}$ & $\mathrm{C}$ & $\mathrm{C}$ \\
\hline \multirow[t]{2}{*}{ US8 } & H.H. Burdsall & US & $\underline{\mathbf{A}}$ & $\underline{\mathbf{C}}$ & $\underline{\mathbf{G}}$ & $\underline{\mathbf{T}}$ & $\underline{\mathrm{C}}$ & $\underline{\mathbf{T}}$ \\
\hline & & & $\mathrm{C}$ & $\mathrm{T}$ & $\mathrm{C}$ & $\mathrm{C}$ & $\mathrm{C}$ & $\mathrm{C}$ \\
\hline \multirow[t]{2}{*}{ CMW3299 } & R.F. Cain & Canada & $\mathrm{C}$ & $\mathrm{T}$ & $\mathrm{C}$ & $\mathrm{C}$ & $\mathrm{C}$ & $\mathrm{C}$ \\
\hline & & & $\mathrm{C}$ & $\mathrm{T}$ & $\mathrm{C}$ & $\mathrm{C}$ & $\mathrm{C}$ & $\mathrm{C}$ \\
\hline \multirow[t]{2}{*}{ GRWSP3 } & B. Slippers & Greece & $\mathrm{C}$ & $\mathrm{T}$ & $\mathrm{C}$ & $\mathrm{C}$ & $\mathrm{C}$ & $\mathrm{C}$ \\
\hline & & & $\mathrm{C}$ & $\mathrm{T}$ & $\mathrm{C}$ & C & $\mathrm{C}$ & $\mathrm{C}$ \\
\hline \multirow[t]{2}{*}{ WSP25It } & B. Slippers & Italy & $\mathrm{C}$ & $\mathrm{T}$ & $\mathrm{C}$ & $\mathrm{C}$ & $\mathrm{C}$ & $\mathrm{C}$ \\
\hline & & & $\mathrm{C}$ & $\mathrm{T}$ & C & C & $\mathrm{C}$ & $\mathrm{C}$ \\
\hline \multirow[t]{2}{*}{ It 1.8} & B. Slippers & Italy & $\mathrm{C}$ & $\mathrm{T}$ & $\mathrm{C}$ & $\mathrm{C}$ & $\mathrm{C}$ & $\mathrm{C}$ \\
\hline & & & $\mathrm{C}$ & $\mathrm{T}$ & $\mathrm{C}$ & $\mathrm{C}$ & $\mathrm{C}$ & $\mathrm{C}$ \\
\hline
\end{tabular}

${ }^{\text {a }}$ Polymorphisms located in introns are indicated with asterisks 
Supplementary Table 3. List of the primers used for PCR.

\begin{tabular}{|c|c|c|}
\hline Primer & Sequence 5'to 3' & Reference \\
\hline rab1 & TTATGAAGCGGGTCGCTACAAG & This study \\
\hline RAB2 & TACAGCCATGACCATCTGGAACTT & $"$ \\
\hline RAB3 & CGTGTACCCCAAGGTCATCT & $"$ \\
\hline RAB4 & CCGAGTCTCGACGTA CAACC & $"$ \\
\hline RAB5 & CCAGACGTCGACCTCACAT & $"$ \\
\hline RABF & CTGGCCTACGTCCTCGTCTA & $"$ \\
\hline RABR & GTATGTAGCGGCTGGAGTTG & $"$ \\
\hline RAB7 & TGGCCTACGTCCTCGTCTAT & $"$ \\
\hline RAB8 & AGGGGTTGTACGTTGAGACG & $"$ \\
\hline RAB9 & GTCTTCTCCGCCTTCTCCTTC & $"$ \\
\hline RAB 10 & CCAGACGTCGACCTCACAT & $"$ \\
\hline RAB 11 & TTGTTTTCCATGTCCCCTTC & $"$ \\
\hline RAB 12 & ATTCCGTAGGCGAAAACTCC & $"$ \\
\hline RAB1-470F & TCTTGGGCTGACTTTTCC & van der Nest et al., 2008 \\
\hline RAB 1-1800R & GGCAGGTAGATCGAGGTTG & van der Nest et al., 2008 \\
\hline BR1-F & TGGCATMTNCARGCNTGGAAYTC & James et al., 2004b \\
\hline BR1-1R & GCGAGNRNCATNAGNCGNAKGTA & James et al., 2004b \\
\hline ITS1 & TCCGTAGGTGAACCTGCGG & White et al., 1990 \\
\hline ITS4 & TCCTCCGCTTATTGATATGC & White et al., 1990 \\
\hline TEFac1 & TCCTGGAGAGGAAGACGAAG & This study \\
\hline TEFac 2 & GTTCGAGGCTGGTATCTCCC & $"$ \\
\hline TEFaa1 & AGACGTCCTGGAGAGGAAGG & $"$ \\
\hline TEFaa2 & GGTATCTCCAAGGACGGTCA & $"$ \\
\hline
\end{tabular}


Supplementary Table 4. The nucleotide polymorphisms in the Tef-1 $\alpha$, ITS and Rab1 sequences in the 13 A. areolatum isolates.

\begin{tabular}{|c|c|c|c|c|c|c|c|c|c|c|c|c|c|c|c|c|c|c|c|c|}
\hline \multirow{3}{*}{$\begin{array}{l}\text { Isolate } \\
\text { number }\end{array}$} & \multirow{3}{*}{$\begin{array}{l}\text { Geographic } \\
\text { origin }\end{array}$} & \multicolumn{19}{|c|}{ Nucleotide polymorphisms } \\
\hline & & \multirow{2}{*}{$\begin{array}{l}\text { ITS } \\
540\end{array}$} & \multicolumn{6}{|c|}{ Tef-1alpha type 1} & \multicolumn{12}{|c|}{$r a b 1$} \\
\hline & & & 81 & 147 & 267 & 312 & 330 & 341 & 62 & 74 & 78 & 89 & 91 & 95 & 150 & 159 & 288 & 375 & 569 & 605 \\
\hline & & & & $*$ & & $*$ & $*$ & $*$ & * & $*$ & $*$ & $*$ & * & $*$ & & & & & $*$ & $*$ \\
\hline \multirow[t]{2}{*}{ LVAA36 } & Sweden & $\mathbf{T}$ & $\mathbf{T}$ & $\mathbf{C}$ & $\mathbf{C}$ & $\mathbf{A}$ & $\mathbf{A}$ & $\mathbf{T}$ & $\mathbf{C}$ & $\mathbf{T}$ & $\mathbf{G}$ & $\mathbf{C}$ & G & $\mathbf{T}$ & $\mathbf{A}$ & $\mathbf{A}$ & $\mathbf{C}$ & $\mathbf{C}$ & G & $\mathbf{T}$ \\
\hline & & $\mathbf{T}$ & $\mathbf{T}$ & $\mathrm{C}$ & C & $\mathbf{A}$ & $\mathbf{A}$ & $\mathbf{T}$ & $\mathrm{C}$ & $\mathrm{T}$ & G & $\mathrm{T}$ & $\mathrm{G}$ & $\mathrm{T}$ & A & A & $\mathrm{C}$ & $\mathrm{C}$ & G & $\mathrm{T}$ \\
\hline \multirow[t]{2}{*}{ L7AA14 } & Lithuania & $\mathrm{C}$ & $\mathbf{T}$ & $\mathrm{C}$ & C & G & A & $\mathbf{T}$ & $\mathrm{C}$ & $\mathrm{T}$ & $\mathrm{G}$ & $\mathrm{T}$ & $\mathrm{G}$ & $\mathrm{T}$ & A & $\mathrm{A}$ & $\mathrm{C}$ & $\mathrm{C}$ & G & $\mathrm{T}$ \\
\hline & & $\mathrm{C}$ & $\mathrm{C}$ & $\mathrm{T}$ & $\mathrm{T}$ & A & G & $\mathrm{T}$ & $\mathrm{C}$ & $\mathrm{T}$ & $\mathrm{G}$ & $\mathrm{T}$ & $\mathrm{G}$ & $\mathrm{T}$ & A & A & $\mathrm{C}$ & $\mathrm{C}$ & G & $\mathrm{T}$ \\
\hline \multirow[t]{2}{*}{ LVAA74 } & Lithuania & $\mathrm{C}$ & $\mathbf{T}$ & $\mathrm{C}$ & C & G & A & $\mathbf{T}$ & $\mathrm{C}$ & $\mathrm{T}$ & G & $\mathrm{T}$ & $\mathrm{G}$ & $\mathrm{T}$ & A & $\mathrm{A}$ & $\mathrm{C}$ & $\mathrm{C}$ & G & $\mathrm{T}$ \\
\hline & & $\mathrm{C}$ & $\mathrm{C}$ & $\mathrm{T}$ & $\mathrm{T}$ & A & G & $\mathrm{T}$ & $\mathrm{C}$ & $\mathrm{T}$ & G & $\mathrm{T}$ & $\mathrm{G}$ & $\mathrm{T}$ & A & $\mathrm{A}$ & $\mathrm{C}$ & $\mathrm{C}$ & G & $\mathrm{T}$ \\
\hline \multirow[t]{2}{*}{ LIIAA221 } & Lithuania & $\mathrm{C}$ & $\mathbf{T}$ & $\mathrm{C}$ & C & G & A & $\mathbf{T}$ & $\mathrm{C}$ & $\mathrm{T}$ & G & $\mathrm{T}$ & $\mathrm{G}$ & $\mathrm{T}$ & A & $\mathrm{A}$ & $\mathrm{C}$ & $\mathrm{C}$ & G & $\mathrm{T}$ \\
\hline & & $\mathrm{C}$ & $\mathbf{T}$ & C & C & G & A & $T$ & $\mathrm{C}$ & $\mathrm{T}$ & G & $\mathrm{T}$ & G & $\mathrm{T}$ & A & A & $\mathrm{C}$ & $\mathrm{C}$ & G & $\mathrm{T}$ \\
\hline \multirow[t]{2}{*}{ DAA12(12) } & Denmark & $\mathbf{T}$ & $\mathrm{T}$ & $\mathrm{C}$ & $\mathrm{C}$ & $\mathrm{A}$ & A & $\mathrm{T}$ & $\mathrm{C}$ & $\mathbf{T}$ & $\mathbf{G}$ & $\mathrm{C}$ & $\mathbf{G}$ & $T$ & $\mathbf{A}$ & $\mathbf{A}$ & $\mathrm{C}$ & C & G & $\mathbf{T}$ \\
\hline & & $\mathrm{C}$ & $\mathrm{C}$ & $\mathbf{T}$ & $\mathbf{T}$ & $\mathbf{A}$ & G & $\mathrm{C}$ & $\mathrm{C}$ & $\mathrm{T}$ & G & $\mathrm{T}$ & G & $\mathrm{T}$ & A & $\mathrm{A}$ & $\mathrm{C}$ & $\mathrm{C}$ & G & $\mathrm{T}$ \\
\hline \multirow[t]{2}{*}{ DAA37(A) } & Denmark & $\mathbf{T}$ & $\mathrm{C}$ & $\mathbf{T}$ & $T$ & $\mathbf{A}$ & G & C & $\mathrm{C}$ & $\mathbf{T}$ & G & $\mathrm{C}$ & G & $T$ & $\mathbf{A}$ & $\mathbf{A}$ & $\mathrm{C}$ & C & G & $\mathbf{T}$ \\
\hline & & $\mathbf{T}$ & $\mathbf{T}$ & $\mathrm{C}$ & C & $\mathbf{A}$ & A & $T$ & $\mathrm{C}$ & $\mathrm{T}$ & G & $\mathrm{T}$ & $\mathrm{G}$ & $\mathrm{T}$ & A & $\mathrm{A}$ & $\mathrm{C}$ & $\mathrm{C}$ & G & $\mathrm{T}$ \\
\hline \multirow[t]{2}{*}{ CMW28225 } & Denmark & $\mathrm{C}$ & $\mathbf{T}$ & C & C & $\mathbf{A}$ & A & $\mathbf{T}$ & $\mathrm{C}$ & $\mathbf{T}$ & $\mathbf{G}$ & $\mathrm{C}$ & G & $\mathbf{T}$ & $\mathbf{A}$ & $\mathbf{A}$ & $\mathrm{C}$ & C & $\mathbf{G}$ & $\mathbf{T}$ \\
\hline & & $\mathrm{C}$ & $\mathbf{T}$ & $\mathrm{C}$ & C & $\mathbf{A}$ & A & $\mathbf{T}$ & $\mathrm{C}$ & $\mathrm{T}$ & G & $\mathrm{T}$ & $\mathrm{G}$ & $\mathrm{T}$ & A & A & $\mathrm{C}$ & $\mathrm{C}$ & $\mathrm{G}$ & $\mathrm{T}$ \\
\hline
\end{tabular}




\begin{tabular}{|c|c|c|c|c|c|c|c|c|c|c|c|c|c|c|c|c|c|c|c|c|}
\hline \multirow[t]{2}{*}{ CMW8900 } & South Africa & $\mathrm{C}$ & $\mathrm{C}$ & $\mathrm{T}$ & $\mathrm{T}$ & A & G & $\mathrm{T}$ & $\underline{\mathbf{T}}$ & $\underline{\mathrm{C}}$ & $\underline{\mathbf{A}}$ & $\underline{\mathbf{T}}$ & $\underline{\mathbf{T}}$ & $\underline{\mathbf{G}}$ & $\underline{\mathbf{G}}$ & $\underline{\mathbf{G}}$ & $\underline{\mathbf{T}}$ & $\underline{\mathbf{T}}$ & $\underline{\mathbf{T}}$ & $\underline{\mathrm{C}}$ \\
\hline & & $\mathrm{C}$ & C & $\mathbf{T}$ & $\mathbf{T}$ & $\mathbf{A}$ & G & $\mathrm{C}$ & $\mathbf{C}$ & $\mathbf{T}$ & $\mathbf{G}$ & $\mathbf{C}$ & G & $\mathbf{T}$ & $\mathbf{A}$ & $\mathbf{A}$ & $\mathrm{C}$ & $\mathrm{C}$ & G & $\mathbf{T}$ \\
\hline \multirow[t]{2}{*}{ CWM3300 } & New Zealand & $\mathrm{C}$ & $\mathrm{C}$ & $\mathrm{T}$ & $\mathrm{T}$ & $\mathrm{A}$ & G & $\mathrm{T}$ & $\underline{\mathbf{T}}$ & $\underline{\mathrm{C}}$ & $\underline{\mathbf{A}}$ & $\underline{\mathbf{T}}$ & $\underline{\mathbf{T}}$ & $\underline{\mathbf{G}}$ & $\underline{\mathbf{G}}$ & $\underline{\mathbf{G}}$ & $\underline{\mathbf{T}}$ & $\underline{\mathbf{T}}$ & $\underline{T}$ & $\underline{\mathrm{C}}$ \\
\hline & & $\mathrm{C}$ & C & $\mathbf{T}$ & $\mathbf{T}$ & $\mathbf{A}$ & G & $\mathrm{C}$ & $\mathrm{C}$ & $\mathbf{T}$ & G & $\mathrm{C}$ & G & $\mathbf{T}$ & $\mathbf{A}$ & $\mathbf{A}$ & $\mathbf{C}$ & $\mathrm{C}$ & G & $\mathbf{T}$ \\
\hline \multirow[t]{2}{*}{ ArA8 } & Argentinia & $\mathrm{C}$ & C & $\mathbf{T}$ & $\mathbf{T}$ & $\mathbf{A}$ & G & $\mathrm{C}$ & $\underline{\mathbf{T}}$ & $\underline{\mathrm{C}}$ & $\underline{\mathbf{A}}$ & $\underline{\mathbf{T}}$ & $\underline{\mathbf{T}}$ & $\underline{\mathbf{G}}$ & $\underline{\mathbf{G}}$ & $\underline{\mathbf{G}}$ & $\underline{\mathbf{T}}$ & $\underline{\mathbf{T}}$ & $\underline{\mathbf{T}}$ & $\underline{\mathrm{C}}$ \\
\hline & & $\mathrm{C}$ & C & $\mathbf{T}$ & $\mathbf{T}$ & $\mathbf{A}$ & G & $\mathrm{C}$ & $\mathrm{C}$ & $\mathbf{T}$ & G & $\mathrm{C}$ & G & $\mathbf{T}$ & $\mathbf{A}$ & $\mathbf{A}$ & $\mathbf{C}$ & $\mathrm{C}$ & G & $\mathbf{T}$ \\
\hline \multirow[t]{2}{*}{ CMW16828 } & Austria & $\mathrm{C}$ & $\mathrm{C}$ & $\mathrm{T}$ & $\mathrm{T}$ & A & G & $\mathrm{T}$ & $\mathrm{C}$ & $\mathrm{T}$ & G & $\mathrm{T}$ & G & $\mathrm{T}$ & A & $\mathrm{A}$ & $\mathrm{C}$ & $\mathrm{C}$ & G & $\mathrm{T}$ \\
\hline & & $\mathrm{C}$ & C & $\mathrm{T}$ & $\mathrm{C}$ & $\mathbf{A}$ & G & $\mathrm{T}$ & $\mathrm{C}$ & $\mathrm{T}$ & $\mathrm{G}$ & $\mathrm{T}$ & $\mathrm{G}$ & $\mathrm{T}$ & A & A & $\mathrm{C}$ & $\mathrm{C}$ & G & $\mathrm{T}$ \\
\hline \multirow[t]{2}{*}{ CMW28221 } & Norway & $\mathrm{C}$ & C & $\mathbf{T}$ & $\mathbf{T}$ & $\mathbf{A}$ & G & C & $\mathrm{C}$ & $\mathrm{T}$ & G & $\mathrm{T}$ & $\mathrm{G}$ & $\mathrm{T}$ & A & A & $\mathrm{C}$ & $\mathrm{C}$ & G & $\mathrm{T}$ \\
\hline & & $\mathrm{C}$ & $\mathrm{T}$ & $\mathrm{C}$ & $\mathrm{C}$ & A & A & $\mathrm{T}$ & $\mathrm{C}$ & $\mathbf{T}$ & G & $\mathrm{C}$ & $\mathbf{G}$ & $\mathbf{T}$ & $\mathbf{A}$ & $\mathbf{A}$ & C & $\mathrm{C}$ & G & $\mathbf{T}$ \\
\hline \multirow[t]{2}{*}{ CMW28224 } & Switzerland & $\mathrm{C}$ & $\mathrm{N}$ & $\mathrm{N}$ & $\mathrm{N}$ & $\mathrm{N}$ & $\mathrm{N}$ & $\mathrm{N}$ & $\underline{\mathbf{T}}$ & $\underline{\mathrm{C}}$ & $\underline{\mathbf{A}}$ & $\underline{T}$ & $\underline{T}$ & $\underline{\mathbf{G}}$ & $\underline{\mathbf{G}}$ & $\underline{\mathbf{G}}$ & $\underline{T}$ & $\underline{\mathbf{T}}$ & $\underline{\mathbf{T}}$ & $\underline{\mathrm{C}}$ \\
\hline & & $\mathrm{C}$ & $\mathrm{N}$ & $\mathrm{N}$ & $\mathrm{N}$ & $\mathrm{N}$ & $\mathrm{N}$ & $\mathrm{N}$ & $\mathrm{C}$ & $\mathbf{T}$ & G & $\mathrm{C}$ & G & $\mathbf{T}$ & $\mathbf{A}$ & $\mathbf{A}$ & C & $\mathrm{C}$ & G & $\mathbf{T}$ \\
\hline
\end{tabular}

${ }^{\text {a }}$ Polymorphisms located in introns are indicated with asterisks 
Supplementary Table 5. The nucleotide polymorphisms in the Tef-1 $\alpha$, ITS and Rab1 sequences in the 13 A. chailletii isolates.

\begin{tabular}{|c|c|c|c|c|c|c|c|c|c|c|c|c|c|c|c|c|c|c|c|c|c|c|c|c|c|}
\hline \multirow{3}{*}{$\begin{array}{l}\text { Isolate } \\
\text { number }\end{array}$} & \multirow{3}{*}{$\begin{array}{l}\text { Geographic } \\
\text { origin }\end{array}$} & \multicolumn{24}{|c|}{ Nucleotide polymorphisms $^{\mathrm{a}}$} \\
\hline & & \multicolumn{6}{|c|}{ ITS } & \multicolumn{8}{|c|}{ Tef-1 $\alpha$} & \multicolumn{10}{|c|}{$r a b 1$} \\
\hline & & 97 & 144 & 193 & 220 & 504 & 512 & 129 & 135 & 162 & 325 & 343 & 358 & 486 & 498 & 87 & 92 & 103 & 130 & 160 & 260 & 280 & 391 & 553 & $615^{b}$ \\
\hline & & & & & & & & $*$ & $*$ & & * & * & & & & $*$ & $*$ & * & & & & & & $*$ & $*$ \\
\hline \multirow[t]{2}{*}{ LvAc113 } & Lithuania & $\mathbf{A}$ & $\mathbf{A}$ & - & G & G & $\mathrm{C}$ & C & $\mathbf{T}$ & $\mathbf{A}$ & $\mathrm{C}$ & $\mathrm{C}$ & C & $\mathbf{C}$ & $\mathbf{T}$ & C & $\mathbf{T}$ & $\mathrm{C}$ & $\mathbf{C}$ & $\mathrm{C}$ & $\mathbf{A}$ & G & $\mathrm{C}$ & insert & - \\
\hline & & $\mathrm{A}$ & G & - & C & G & $\mathrm{C}$ & C & $\mathbf{T}$ & $\mathbf{A}$ & C & $\mathrm{C}$ & $\mathrm{C}$ & C & C & C & $\mathbf{T}$ & C & $\mathbf{C}$ & C & $\mathbf{A}$ & G & C & Insert & - \\
\hline \multirow[t]{2}{*}{ LIIAc116 } & Lithuania & A & G & - & C & G & C & $\underline{\mathbf{C}}$ & $\underline{T}$ & $\underline{\mathbf{A}}$ & $\underline{\mathrm{C}}$ & $\underline{\mathbf{C}}$ & $\underline{\mathbf{C}}$ & $\underline{\mathbf{T}}$ & $\underline{\mathrm{C}}$ & $\mathrm{C}$ & $\mathrm{T}$ & C & $\mathrm{C}$ & $\mathrm{C}$ & G & $\mathrm{G}$ & $\mathrm{C}$ & Insert & inser \\
\hline & & $\mathrm{A}$ & G & - & $\mathrm{C}$ & G & $\mathrm{C}$ & $\mathbf{T}$ & - & G & $\mathbf{T}$ & $\mathbf{T}$ & $\mathbf{T}$ & C & $\mathbf{T}$ & $\mathbf{C}$ & $\mathbf{T}$ & C & $\mathbf{C}$ & C & $\mathbf{A}$ & G & $\mathbf{C}$ & Insert & - \\
\hline \multirow[t]{2}{*}{ GBAC56.4 } & UK & $\mathbf{A}$ & G & - & G & $\mathbf{A}$ & $\mathrm{C}$ & $\underline{\mathrm{C}}$ & $\underline{T}$ & $\underline{\mathbf{A}}$ & $\underline{\mathrm{C}}$ & $\underline{\mathbf{C}}$ & $\underline{\mathbf{C}}$ & $\underline{T}$ & $\underline{\mathrm{C}}$ & $\mathbf{C}$ & $\mathbf{T}$ & $\mathrm{C}$ & $\mathbf{C}$ & C & $\mathbf{A}$ & G & C & Insert & - \\
\hline & & $\underline{\mathbf{A}}$ & $\underline{\mathbf{A}}$ & $\underline{\mathbf{A}}$ & $\underline{\mathbf{G}}$ & $\underline{\mathbf{G}}$ & $\underline{\mathrm{C}}$ & $\mathbf{T}$ & - & G & $\mathbf{T}$ & $\mathbf{T}$ & $\mathbf{T}$ & $T$ & C & $\mathrm{C}$ & $\mathrm{T}$ & C & $\mathrm{C}$ & $\mathrm{C}$ & $\mathrm{G}$ & G & $\mathrm{C}$ & Insert & inser \\
\hline \multirow[t]{2}{*}{ GBAC62.9 } & UK & $\mathbf{A}$ & G & - & G & $\mathbf{A}$ & C & C & $\mathbf{T}$ & $\mathbf{A}$ & C & $\mathbf{C}$ & $\mathrm{C}$ & C & $\mathbf{T}$ & $\mathbf{C}$ & $\mathbf{T}$ & $\mathrm{C}$ & $\mathbf{C}$ & C & $\mathbf{A}$ & G & C & Insert & - \\
\hline & & $\underline{\mathbf{A}}$ & $\underline{\mathbf{A}}$ & $\underline{\mathbf{A}}$ & $\underline{\mathbf{G}}$ & $\underline{\mathbf{G}}$ & $\underline{\mathrm{C}}$ & C & $\mathbf{T}$ & $\mathbf{A}$ & $\mathrm{C}$ & $\mathbf{C}$ & $\mathbf{C}$ & $\mathbf{C}$ & C & $\mathbf{C}$ & $\mathbf{T}$ & C & C & C & $\mathbf{A}$ & G & C & Insert & - \\
\hline \multirow[t]{2}{*}{ DAC2 } & Denmark & A & G & - & $\mathrm{C}$ & G & C & $\mathbf{C}$ & $\mathbf{T}$ & $\mathbf{A}$ & C & $\mathbf{C}$ & $\mathbf{C}$ & $\mathbf{C}$ & $\mathbf{T}$ & $\mathbf{C}$ & $\mathbf{T}$ & C & $\mathbf{C}$ & C & $\mathbf{A}$ & G & C & Insert & - \\
\hline & & $\underline{\mathbf{A}}$ & $\underline{\mathbf{A}}$ & $\underline{\mathbf{A}}$ & $\underline{\mathbf{G}}$ & $\underline{\mathbf{G}}$ & $\underline{C}$ & $\mathbf{C}$ & $\mathbf{T}$ & $\mathbf{A}$ & $\mathrm{C}$ & $\mathbf{C}$ & $\mathbf{C}$ & $\mathbf{C}$ & $\mathbf{T}$ & $\mathbf{C}$ & $\mathbf{T}$ & C & $\mathbf{C}$ & C & $\mathbf{A}$ & G & C & Insert & - \\
\hline \multirow[t]{2}{*}{ DAC28 } & Denmark & A & G & - & C & G & C & C & $\mathbf{T}$ & $\mathbf{A}$ & C & $\mathbf{C}$ & $\mathbf{C}$ & $\mathbf{C}$ & $\mathbf{T}$ & $\mathrm{C}$ & $\mathrm{T}$ & $\mathrm{C}$ & $\mathrm{C}$ & $\mathrm{C}$ & G & G & $\mathrm{C}$ & Insert & inser \\
\hline & & $\mathbf{A}$ & $\mathbf{A}$ & - & G & G & C & C & $\mathbf{T}$ & $\mathbf{A}$ & C & $\mathbf{C}$ & $\mathbf{C}$ & $\mathbf{C}$ & $\mathbf{T}$ & $\mathrm{C}$ & $\mathrm{T}$ & $\mathrm{C}$ & $\mathrm{C}$ & $\mathrm{C}$ & G & G & $\mathrm{C}$ & Insert & inser \\
\hline \multirow[t]{2}{*}{ DAC44 } & Denmark & G & G & - & $\mathbf{G}$ & A & $\mathbf{T}$ & $\mathbf{T}$ & - & G & $\mathbf{T}$ & $\mathbf{T}$ & $\mathbf{T}$ & $\mathbf{T}$ & C & $\mathrm{C}$ & $\mathrm{T}$ & $\mathrm{C}$ & $\mathrm{C}$ & $\mathrm{C}$ & G & G & $\mathrm{C}$ & Insert & inser \\
\hline & & $\mathbf{A}$ & G & - & G & $\mathbf{A}$ & C & $\mathbf{T}$ & - & G & $\mathrm{T}$ & $T$ & $\mathbf{T}$ & $T$ & C & $\mathrm{C}$ & $\mathrm{T}$ & $\mathrm{C}$ & $\mathrm{C}$ & $\mathrm{C}$ & G & G & $\mathrm{C}$ & Insert & inser \\
\hline
\end{tabular}




\begin{tabular}{|c|c|c|c|c|c|c|c|c|c|c|c|c|c|c|c|c|c|c|c|c|c|c|c|c|c|}
\hline \multirow[t]{2}{*}{ DAC66B } & Denmark & $\mathbf{A}$ & $\mathbf{A}$ & - & G & G & $\mathbf{C}$ & $\underline{\mathrm{C}}$ & $\underline{T}$ & $\underline{\mathbf{A}}$ & $\underline{\mathbf{C}}$ & $\underline{\mathbf{C}}$ & $\underline{\mathbf{C}}$ & $\underline{\mathbf{T}}$ & $\underline{\mathbf{C}}$ & $\mathbf{C}$ & $\mathbf{T}$ & $\mathbf{C}$ & C & C & $\mathbf{A}$ & G & $\mathbf{C}$ & Insert & - \\
\hline & & $\mathbf{A}$ & $\mathbf{A}$ & - & G & G & $\mathrm{C}$ & $\underline{C}$ & $\underline{\mathbf{T}}$ & $\underline{\mathbf{A}}$ & $\underline{\mathbf{C}}$ & $\underline{\mathbf{C}}$ & $\underline{\mathbf{C}}$ & $\underline{\mathbf{T}}$ & $\underline{\mathrm{C}}$ & $\mathbf{C}$ & $\mathbf{T}$ & C & $\mathrm{C}$ & $\mathrm{C}$ & $\mathbf{A}$ & G & C & Insert & - \\
\hline \multirow[t]{2}{*}{ DAC177 } & Denmark & $\mathbf{A}$ & $\mathbf{A}$ & - & G & G & C & $\underline{\mathrm{C}}$ & $\underline{T}$ & $\underline{\mathbf{A}}$ & $\underline{\mathbf{C}}$ & $\underline{\mathrm{C}}$ & $\underline{\mathrm{C}}$ & $\underline{T}$ & $\underline{\mathrm{C}}$ & C & $\mathbf{T}$ & C & C & C & $\mathbf{A}$ & G & $\mathbf{C}$ & Insert & - \\
\hline & & $\underline{\mathbf{A}}$ & $\underline{\mathbf{A}}$ & $\underline{\mathbf{A}}$ & $\underline{\mathbf{G}}$ & $\underline{\mathbf{G}}$ & $\underline{\mathrm{C}}$ & C & $\mathbf{T}$ & $\mathbf{A}$ & C & C & C & C & $\mathbf{T}$ & C & $\mathbf{T}$ & C & C & C & $\mathbf{A}$ & G & C & Insert & - \\
\hline \multirow[t]{2}{*}{ US1 } & US & G & G & - & G & $\mathbf{A}$ & $\mathbf{T}$ & $\mathbf{n}$ & $\mathbf{N}$ & $\mathbf{n}$ & $\mathbf{n}$ & $\mathbf{n}$ & $\mathbf{n}$ & $\mathbf{n}$ & $\mathbf{n}$ & C & $\mathbf{T}$ & C & C & C & $\mathbf{A}$ & G & C & Insert & - \\
\hline & & $\mathbf{A}$ & G & - & G & $\mathbf{A}$ & $\mathrm{C}$ & $\mathbf{n}$ & $\mathbf{N}$ & $\mathbf{n}$ & $\mathbf{n}$ & $\mathbf{n}$ & $\mathbf{n}$ & $\mathbf{n}$ & $\mathbf{n}$ & $\underline{\mathrm{A}}$ & $\underline{\mathrm{C}}$ & $\underline{\mathrm{G}}$ & $\underline{T}$ & $\underline{T}$ & $\underline{\mathrm{G}}$ & $\underline{\mathrm{A}}$ & $\underline{\mathrm{G}}$ & $=$ & $\underline{\text { insert }}$ \\
\hline \multirow[t]{2}{*}{ US2 } & US & $\mathbf{A}$ & G & - & G & $\mathbf{A}$ & C & C & $\mathbf{T}$ & $\mathbf{A}$ & C & C & C & C & $\mathbf{T}$ & C & $\mathbf{T}$ & C & C & C & $\mathbf{A}$ & G & C & Insert & - \\
\hline & & $\mathbf{A}$ & G & - & G & $\mathbf{A}$ & C & C & $\mathbf{T}$ & $\mathbf{A}$ & C & C & C & C & $\mathbf{T}$ & C & $\mathbf{T}$ & C & C & C & $\mathbf{A}$ & G & C & Insert & - \\
\hline \multirow[t]{2}{*}{ WSP25It } & Italy & $\mathbf{A}$ & G & - & G & $\mathbf{A}$ & $\mathrm{C}$ & $\underline{\mathrm{C}}$ & $\underline{T}$ & $\underline{\mathbf{A}}$ & $\underline{\mathrm{C}}$ & $\underline{\mathrm{C}}$ & $\underline{\mathrm{C}}$ & $\underline{\mathbf{T}}$ & $\underline{\mathrm{C}}$ & $\mathrm{C}$ & $\mathrm{T}$ & $\mathrm{C}$ & $\mathrm{C}$ & $\mathrm{C}$ & G & G & $\mathrm{C}$ & insert & insert \\
\hline & & $\mathbf{A}$ & G & - & G & A & C & $\mathbf{T}$ & - & $\mathbf{G}$ & $\mathbf{T}$ & $\mathbf{T}$ & $\mathbf{T}$ & $\mathbf{T}$ & C & C & $\mathbf{T}$ & C & C & C & $\mathbf{A}$ & G & C & Insert & - \\
\hline \multirow[t]{2}{*}{ It 1.8} & Italy & $\underline{\mathbf{A}}$ & $\underline{\mathbf{A}}$ & $\underline{\mathbf{A}}$ & $\underline{\mathbf{G}}$ & $\underline{\mathbf{G}}$ & $\underline{\mathrm{C}}$ & $\underline{\mathbf{C}}$ & $\underline{T}$ & $\underline{\mathbf{A}}$ & $\underline{\mathrm{C}}$ & $\underline{\mathbf{C}}$ & $\underline{\mathbf{C}}$ & $\underline{T}$ & $\underline{\mathrm{C}}$ & C & $\mathbf{T}$ & C & C & C & $\mathbf{A}$ & G & $\mathbf{C}$ & Insert & - \\
\hline & & $\underline{\mathbf{A}}$ & $\underline{\mathbf{A}}$ & $\underline{\mathbf{A}}$ & $\underline{\mathbf{G}}$ & $\underline{\mathbf{G}}$ & $\underline{\mathbf{C}}$ & $\mathbf{C}$ & $\mathbf{T}$ & $\mathbf{A}$ & $\mathbf{C}$ & C & C & C & $\mathbf{T}$ & C & $\mathrm{T}$ & C & C & C & G & $\underline{\mathrm{A}}$ & $\underline{\mathrm{G}}$ & & insert \\
\hline
\end{tabular}

a Polymorphisms located in introns are indicated with asterisks. Deletions are indicated with hyphens and unknown bases with "n".

b insert sequence "TT"

" insert sequence "TCGGCTCCTACCCGCACATGT" 
Supplementary Table 6. Comparison of percentage identity of the rabl alleles present in A. areolatum and A. chailletii.

\begin{tabular}{llccccccc}
\hline Locus & Species & Rab1.1 & Rabl.2 & Rabl.3 & Rabl.4 & Rab1.5 & Rabl.6 & Rabl.7 \\
\hline Rab1.1 & A. areolatum & - & & & & & \\
Rab1.2 & A. areolatum & $98.9^{*}$ & - & & & & \\
Rab1.3 & A. areolatum & 98.9 & 99.8 & - & & & \\
Rab1.4 & A. chailletii & 83.5 & 83.6 & 83.5 & - & & \\
Rab1.5 & A. chailletii & 81.9 & 82.1 & 81.9 & 98.4 & - & \\
Rab1.6 & A. chailletii & 83.0 & 83.1 & 83.0 & 98.6 & 97.0 & - \\
Rab1.7 & A. chailletii & 83.2 & 83.3 & 83.2 & 99.4 & 97.9 & 98.8 \\
\hline
\end{tabular}

${ }^{*}$ The sequence identity is the number of exactly matching residues (expressed as a percentage). 